\title{
World Cancer Research Fund International: Continuous Update Project-systematic literature review and meta-analysis of observational cohort studies on physical activity, sedentary behavior, adiposity, and weight change and breast cancer risk
}

\author{
Doris S. M. Chan ${ }^{1}$ (D) Leila Abar ${ }^{1} \cdot$ Margarita Cariolou $^{1} \cdot$ Neesha Nanu $^{1} \cdot$ Darren C. Greenwood $^{2} \cdot$ Elisa V. Bandera ${ }^{3}$. \\ Anne McTiernan ${ }^{4} \cdot$ Teresa Norat $^{1}$
}

Received: 15 March 2019 / Accepted: 16 August 2019 / Published online: 30 August 2019

(C) The Author(s) 2019

\begin{abstract}
Purpose The purpose of the present study was to systematically review the complex associations between energy balancerelated factors and breast cancer risk, for which previous evidence has suggested different associations in the life course of women and by hormone receptor (HR) status of the tumor.

Methods Relevant publications on adulthood physical activity, sedentary behavior, body mass index (BMI), waist and hip circumferences, waist-to-hip ratio, and weight change and pre- and postmenopausal breast cancer risk were identified in PubMed up to 30 April 2017. Random-effects meta-analyses were conducted to summarize the relative risks across studies. Results One hundred and twenty-six observational cohort studies comprising over 22,900 premenopausal and 103,000 postmenopausal breast cancer cases were meta-analyzed. Higher physical activity was inversely associated with both pre- and postmenopausal breast cancers, whereas increased sitting time was positively associated with postmenopausal breast cancer. Although higher early adult BMI (ages 18-30 years) was inversely associated with pre- and postmenopausal breast cancers, adult weight gain and greater body adiposity increased breast cancer risk in postmenopausal women, and the increased risk was evident for HR+ but not HR- breast cancers, and among never but not current users of postmenopausal hormones. The evidence was less consistent in premenopausal women. There were no associations with adult weight gain, inverse associations with adult BMI (study baseline) and hip circumference, and non-significant associations with waist circumference and waist-to-hip ratio that were reverted to positive associations on average in studies accounting for BMI. No significant associations were observed for HR-defined premenopausal breast cancers.

Conclusion Better understanding on the impact of these factors on pre- and postmenopausal breast cancers and their subtypes along the life course is needed.
\end{abstract}

Keywords Systematic literature review $\cdot$ Breast cancer $\cdot$ Life course $\cdot$ Adiposity $\cdot$ Weight change $\cdot$ Physical activity

\section{Introduction}

Globally, breast cancer is the most frequent cancer and the leading cause of cancer death in women. There were an esti-

Electronic supplementary material The online version of this article (https://doi.org/10.1007/s10552-019-01223-w) contains supplementary material, which is available to authorized users.

Doris S. M. Chan

d.chan@imperial.ac.uk

1 Department of Epidemiology and Biostatistics, School of Public Health, Imperial College London, St. Mary's Campus, Norfolk Place, London W2 1PG, UK mated 2.09 million incident cases and 0.63 million deaths from breast cancer worldwide in 2018 [1], which imposes

School of Medicine, University of Leeds, Leeds, UK

3 Rutgers Cancer Institute of New Jersey, New Brunswick, NJ, USA

4 Division of Public Health Sciences, Fred Hutchinson Cancer Research Center, Seattle, WA, USA 
a considerable burden on public health. While mammography screening reduces breast cancer mortality by up to 40 percent [2], cancer prevention via lifestyle modifications is clearly needed [3]. Overweight and obesity—globally prevalent conditions [4, 5] —manifested by chronic excessive energy intake and inadequate energy expenditure through low physical activity and increased sedentary behavior [6] could be one such target. Physical activity is also an important focus, as it may influence breast cancer risk through mechanisms in addition to body weight modulation [7].

The Third Expert Report published by the World Cancer Research Fund/American Institute for Cancer Research (WCRF/AICR) concluded that there is strong evidence that vigorous physical activity protects against premenopausal breast cancer, moderate or vigorous physical activity protects against postmenopausal breast cancer, and greater body fatness and weight gain in adult life causes postmenopausal breast cancer (https://www.wcrf.org/dietandcancer) [8]. These conclusions supported the recommendations for cancer prevention which promote healthy body weight (World Health Organisation definition: 18.5 to $24.9 \mathrm{~kg} / \mathrm{m}^{2}$ ) and adequate energy balance throughout life (be physically active, eat a diet rich in wholegrains, vegetables, fruit and beans, limit consumption of 'fast foods' and other processed foods high in fat, starches or sugars, and sugar sweetened drinks). Previous studies have shown that adherence to the 2007 WCRF/AICR recommendations [9] is associated with reduced breast cancer risk [10-17], breast cancer mortality [18] and total mortality [19], and improved cancer survival [20]; signifying the importance of healthy lifestyles.

As part of the on-going WCRF International Continuous Update Project (CUP) [21], we conducted a comprehensive systematic review and meta-analysis of the associations between adulthood physical activity, sedentary behavior, body mass index (BMI), waist and hip circumferences, waist-to-hip ratio, and weight change and the risk of overall and estrogen receptor (ER) and/or progesterone receptor (PR)-defined pre- and postmenopausal breast cancer, for which previous evidence has suggested complex differential associations [22-24]. These data contributed to the scientific evidence for the development of cancer prevention recommendations in the WCRF/AICR Third Expert Report [8]. Here, we describe the current knowledge and our findings.

\section{Materials and methods}

Full details of the methods used in the present review are available online in the supplementary material.

\section{Literature search}

Relevant publications were searched in PubMed up to 30th April 2017, using a tested search strategy with no language restriction. Reference lists of related articles were screened.

\section{Study selection}

Inclusion criteria were (1) randomized controlled trials, cohort studies, case-cohort studies, case-control studies within a cohort, or pooled analyses of individual data from studies of these designs; (2) studies that investigated the associations of interest; and (3) studies reporting relative risk, hazard ratio, or odds ratio and its measure of variability.

The publication with more number of cases was selected from multiple publications of the same study or studies of overlapping populations. Pooled analyses that combined case-control studies with cohort studies were excluded [25, 26].

\section{Data extraction}

Study characteristics, participant characteristics, exposure factors and breast cancer outcomes, numbers of cases and non-cases per exposure category, relative risk estimates (RR) with their 95\% confidence intervals (CI) or $p$-values, and covariate adjustment in the analysis were extracted into the CUP database.

\section{Study quality evaluation}

The risk of bias of the included studies was assessed for various aspects relating to menopausal status classification, exposure and outcome ascertainment, and confounding factors adjustment. Supplementary Table S1 shows the scoring criteria.

\section{Statistical methods}

The primary analysis was linear dose-response meta-analysis, conducted when at least three studies report the required information on an association. A summary RR was calculated using a random-effects model, which allows for possible variations of associations across the studies [27].

The procedures to pool the results from individual studies were in accordance with other published meta-analyses [28-31]. This involved the pooling of dose-response estimates that were either directly reported in the studies or calculated by us for the studies reporting RR estimates for at least three exposure levels using the generalized weighted least-squares regression model $[32,33]$. In this method, 
numbers of cases and non-cases or population at risk and exposure values (mean or midpoint of range) per category are needed. If the required information was not available, standard methods were used to impute these [34, 35]; if this could not be done, the study was excluded from the metaanalysis (insufficient data).

For physical activity (any domains) and adulthood weight loss, because the required data for dose-response trend estimation were not reported in most studies, random-effects categorical meta-analyses that compared the highest with the lowest level were also conducted.

Multivariable adjusted estimates were selected for the meta-analyses. Between-study heterogeneity was assessed by the Cochran $Q$ test, and $I^{2}$ statistic [36], and potential heterogeneity sources were explored in pre-defined subgroup meta-analyses and univariate meta-regression analyses [37]. Small study bias such as publication bias was assessed by Egger's test and visual inspection of the funnel plots when there were more than ten studies [38]. Influence analysis was conducted by omitting each study in turn from the meta-analysis. Exploratory non-linear dose-response metaanalysis was conducted when there were five or more studies with at least four exposure categories, using restricted cubic spline regression with three knots $[39,40]$.

A two-tailed $p$-value of $<0.05$ was considered as statistical significant, except for the $p$-value of $<0.10$ in the generally low-powered Egger's test [38]. Statistical package Stata 13.1 (StataCorp, College Station, TX, USA) was used.

\section{Results}

Figure 1 shows the PRISMA flowchart. Overall, 142 publications from 126 observational cohort studies, comprising over 22,900 premenopausal and 103,000 postmenopausal breast cancer cases among 8.53 million women, mostly from North America and Europe, and some from Australia and New Zealand, China, Korea, and Japan were meta-analyzed [14, 41-181]. No randomized controlled trials were identified.

Figures 2, 3, 4, and 5 show the results of the meta-analyses. Supplementary materials: Table $\mathrm{S} 2$ is the list of studies included and excluded with exclusion reason from the metaanalyses, Table S3 shows the main characteristics of the included studies, Table S4 is the PRISMA checklist, Tables S5 to S17 show the results of the subgroup meta-analyses, and Figs. S1 to S52 are the graphical results of the analyses.

\section{Physical activity and premenopausal breast cancer}

Vigorous physical activity was statistically significantly inversely associated with premenopausal breast cancer risk when comparing the highest with the lowest level.
The summary RR was 0.79 (95\% CI 0.69-0.91), with low between-study heterogeneity $\left(I^{2}=6 \%, p\right.$ heterogeneity $=0.37)$ (5 studies) (Fig. S1). The associations were inverse but not significant for total physical activity (recreational, household, occupational physical activity combined) (5 studies), recreational (12 studies), and occupational physical activity (8 studies). There was no association with walking (2 studies) (Figs. 2 and S2-S5).

The associations were not significantly different in the subgroup meta-analyses ( $p$-values for meta-regression $\geq 0.10$ ) (Tables S5 and S6). Dose-response meta-analyses were possible for vigorous and recreational physical activity (3 studies each). The results were not significant (Figs. 3 and S6-S7). In influence analyses, the association became non-significant for vigorous physical activity but remained unchanged for the other domains. There was no indication of small study bias (Egger's test $p=0.89$ ).

\section{Physical activity and postmenopausal breast cancer}

Significant inverse associations for physical activity and postmenopausal breast cancer risk were observed across all domains in the highest versus the lowest meta-analyses, except for walking (Fig. 2). The summary RRs were 0.90 $\left(95 \%\right.$ CI $0.85-0.95 ; I^{2}=0 \%, p$ heterogeneity $\left.=0.96\right)(11$ studies $)$ for vigorous, $0.86\left(0.78-0.94 ; I^{2}=9 \%, p\right.$ heterogeneity $=0.35)$ (6 studies) for total, $0.88\left(0.82-0.94 ; I^{2}=35 \%\right.$, $p$ heterogeneity $=0.06$ ) (21 studies) for recreational, 0.90 $\left(0.85-0.96 ; I^{2}=0 \%, p\right.$ heterogeneity $\left.=0.89\right)(9$ studies $)$ for occupational physical activity, and $0.95\left(0.86-1.04 ; I^{2}=0 \%\right.$, $p$ heterogeneity $=0.98)(4$ studies) for walking (Figs. S1-S5).

In the subgroup meta-analyses by BMI, recreational physical activity was non-significantly inversely associated with postmenopausal breast cancer among women of normal weight (summary RR 0.85, 95\% CI 0.72-1.01) (5,946 cases), and weaker or no associations were observed among women who were overweight $(0.95,0.85-1.06)$ $(3,548$ cases) or obese $(1.00,0.86-1.15)(1,803$ cases) ( $p$ for meta-regression $=0.53$ ) (5 studies [67, 122, 128, 138, 160]) (Fig. S9). The inverse associations were more evident among postmenopausal hormone never users [56, 92, 128, $138,139]$ than ever users [56, 92, 128, 138, 139, 164]; and for vigorous physical activity, stronger for postmenopausal ER- $[110,139]$ than $E R+[108,110,139,141]$ breast cancers (Figs. S10-S13). Meta-analyses of the other subgroups mostly confirmed the inverse associations ( $p$-values for meta-regression $\geq 0.05$ ) (Tables S5-S7).

Limited numbers of studies could be included in the dose-response meta-analyses (Fig. 3). The summary RR was 0.98 (95\% CI 0.97-0.99) per 10 metabolic equivalent of task (MET)-hour/week of recreational physical activity (6 studies). Non-significant associations of similar magnitude 
Fig. 1 PRISMA flowchart: studies of physical activity, sedentary behavior, adiposity, and weight change and breast cancer risk

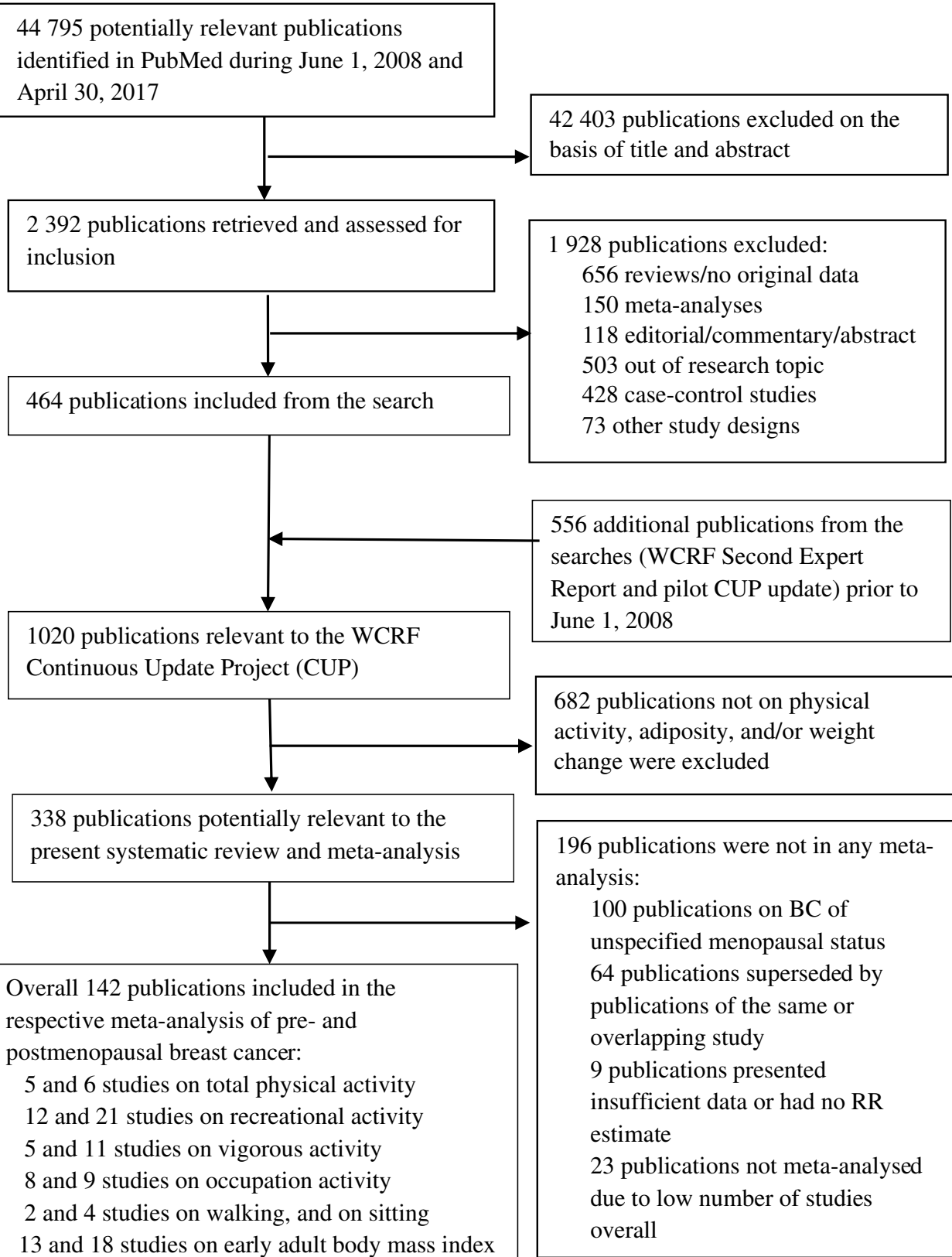

9 and 16 studies on adult weight gain

6 and 9 studies on gain in body mass index

8 and 14 studies on weight loss

40 and 75 studies on body mass index

7 and 23 studies on waist circumference

4 and 16 studies on hip circumference

10 and 29 studies on waist-hip-ratio were observed for total and vigorous physical activity (3 studies each) (Figs. S6-S8).

Non-linear analysis showed no departure from linearity ( $p=0.68$ ) (Fig. S14). The association with total physical activity became non-significant but the summary estimate was unchanged (RR for highest versus lowest level 0.86 ,
95\% CI 0.74-1.00) when one study [160] was omitted from influence analysis. Small study bias was detected in the analysis of recreational physical activity (Egger's test $p=0.01)$. Smaller studies with a stronger than the average inverse association $[42,133,155,182]$ and one study with 

of pre- and postmenopausal breast cancer for the highest versus the lowest categories of physical activity, adiposity, and
Fig. 2 Summary risk estimates weight change

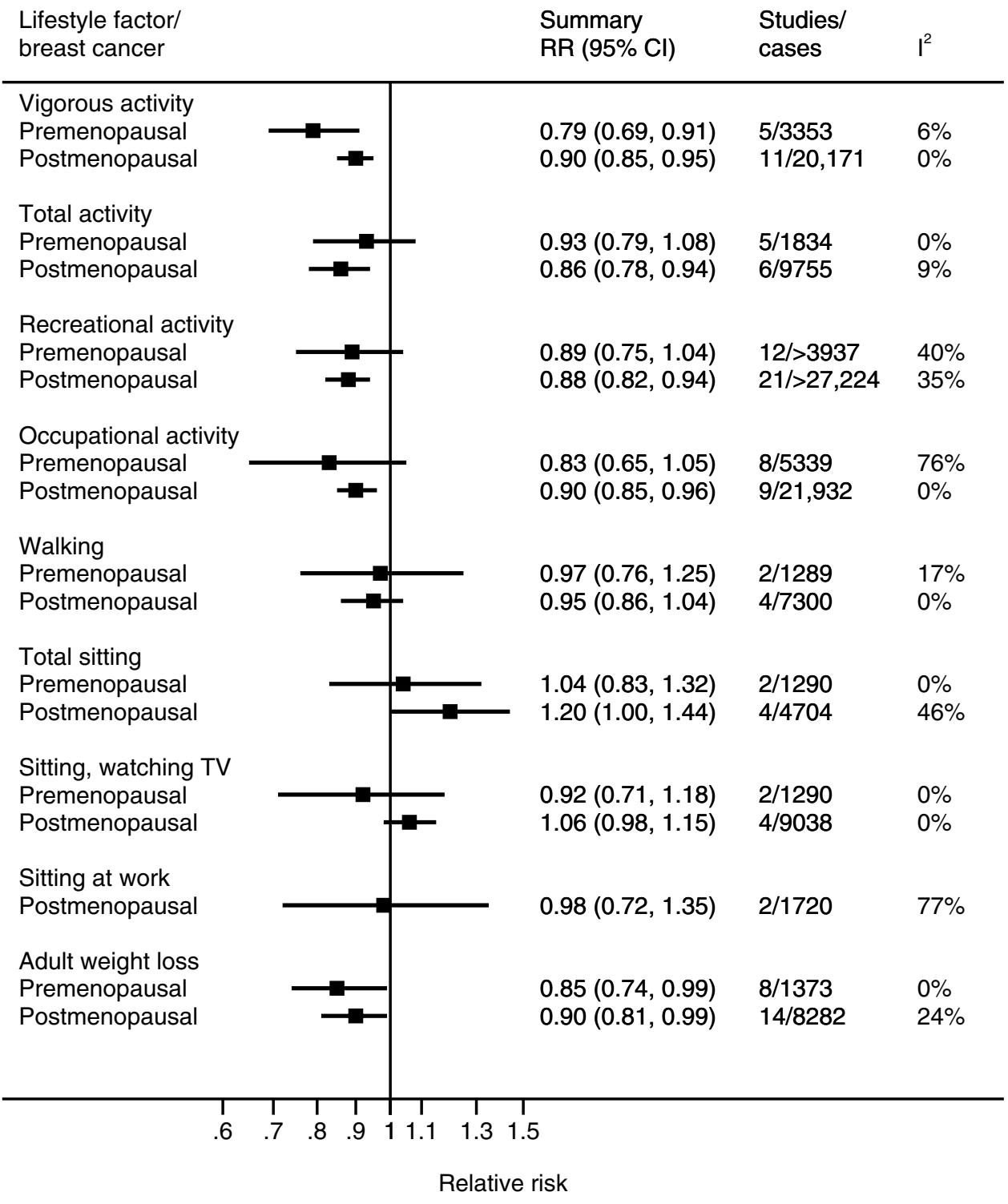

a weaker association [160] may have driven the asymmetry in the funnel plot.

\section{Sedentary behavior and premenopausal and postmenopausal breast cancer}

Increased total sitting time was not associated with premenopausal breast cancer (2 studies) (Fig. 2). However, it was positively associated with postmenopausal breast cancer. The summary RRs were 1.20 (95\% CI 1.00-1.44) for the highest versus the lowest level $\left(I^{2}=46 \%, p\right.$ heterogeneity $=0.13$ ) (4 studies) (Fig. 2) and 1.07 (95\% CI 1.01-1.14) per $5 \mathrm{~h} /$ day $\left(I^{2}=0 \%, p\right.$ heterogeneity $\left.=0.55\right)(3$ studies $)$ (Fig. 3). The associations were not observed for sitting while watching television or at work (Figs. S15-S17) and did not persist in influence analyses.

\section{Early adult body mass index and premenopausal and postmenopausal breast cancer}

Greater early adult BMI (ages 18-30 years) was significantly inversely associated with premenopausal breast cancer. The summary RR was $0.86(95 \%$ CI $0.78-0.96)$ per $5 \mathrm{~kg} / \mathrm{m}^{2}$ $\left(I^{2}=47 \%, p\right.$ heterogeneity $\left.=0.05\right)(13$ studies $)$ (Figs. 3 and S18).

Inverse association of similar magnitude was observed for postmenopausal breast cancer $(0.81,0.75-0.87)$ (Figs. 3 and S18). There was significant between-study heterogeneity $\left(I^{2}=50 \%, p\right.$ heterogeneity $\left.=0.01\right)(18$ studies $)$. Subgroup meta-analyses showed that studies that adjusted for adult BMI or weight gain [68, 87, 99, 136, 154, 162] on average observed a stronger inverse association compared with unadjusted studies [54, 56, 102, 111, 113, 130, 167, 170, 178], and may partially explain the observed heterogeneity 
Fig. 3 Summary risk estimates of pre- and postmenopausal breast cancer per unit increment of physical activity, adiposity, and weight change

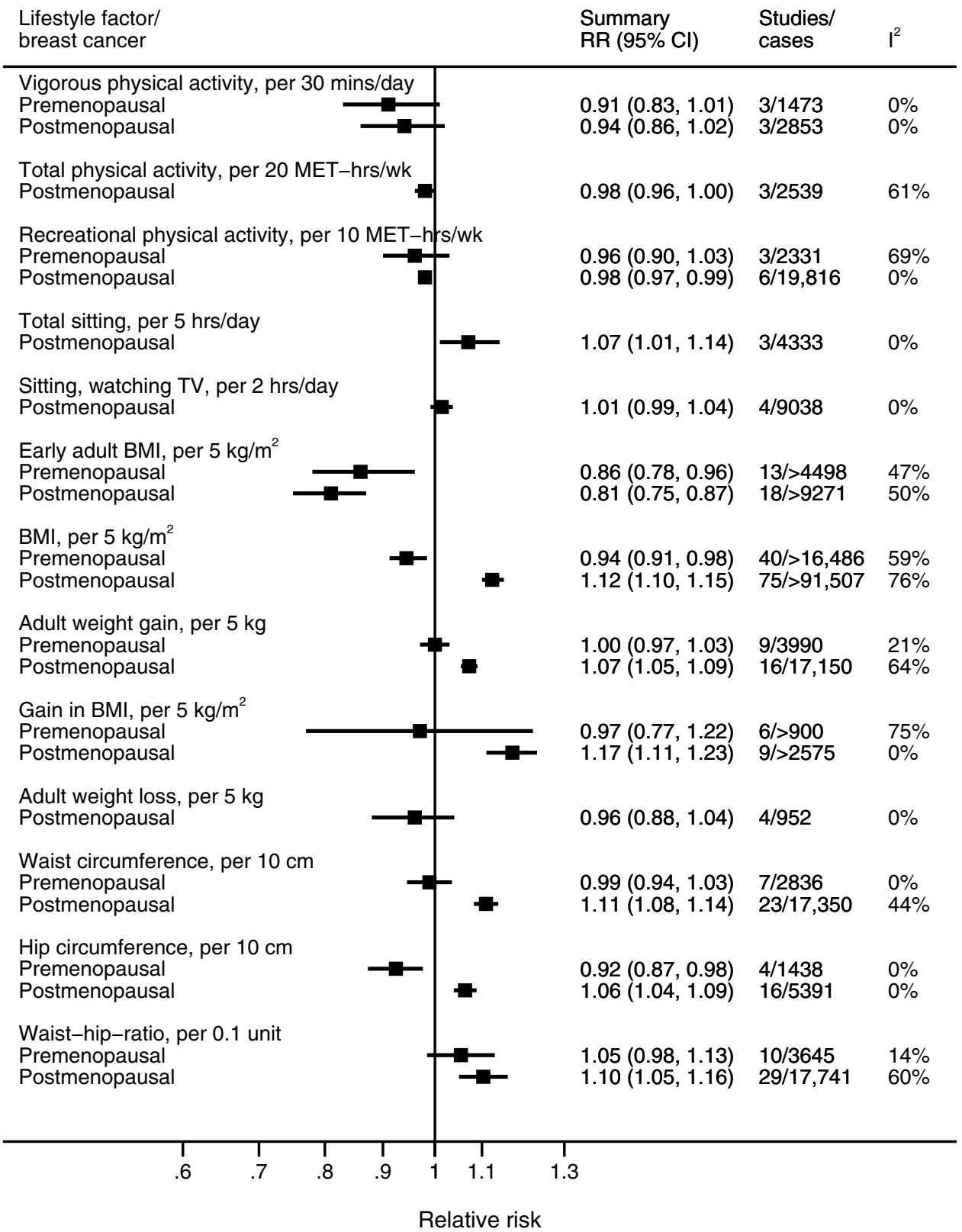

( $p$-value for meta-regression $=0.009)$. Inverse associations persisted across most other subgroups ( $p$-values for metaregression $\geq 0.08$ ) (Table $\mathrm{S} 8$ ).

There were no indications of non-linear relationships $(p \geq 0.29)$ (Figs. S19-S20) or small study bias $(p \geq 0.13)$.

\section{Body mass index and premenopausal breast cancer}

Greater BMI (study baseline) was significantly inversely associated with premenopausal breast cancer. The summary RR was 0.94 (95\% CI $0.91-0.98)$ per $5 \mathrm{~kg} / \mathrm{m}^{2}\left(I^{2}=59 \%, p\right.$ heterogeneity <0.001) (40 studies) (Figs. 3 and S21).

The observed heterogeneity may partially be explained by study location ( $p$ for meta-regression $=0.004$ ). On average, the association was significant and inverse in European studies $[47,49,66,97,106,114,115,119,120,143,168,169$, $171,173,175]$, non-significant and inverse in North American studies [56, 57, 80, 136, 144, 159, 171, 180], but nonsignificant and positive in Asian studies (8 Japanese studies [174] and 1 Chinese study [112]) (Table S9).

BMI was not significantly associated with premenopausal ER+ and ER - breast cancers ( 5 studies, 4 publications [57, 65, 95, 127]) (Fig. S22).

There was no indication of departure from linearity $(p=0.31)$ (Fig. S23). The funnel plot showed asymmetry, probably driven by study heterogeneity $(p=0.06)$. BMI was not associated with premenopausal breast cancer mortality (36 studies, 2 publications [143, 179]) (Fig. S24). 

of effect modification by postmenopausal hormone use in the associations of adiposity and weight change with postmenopausal breast cancer
Fig. 4 Summary risk estimates

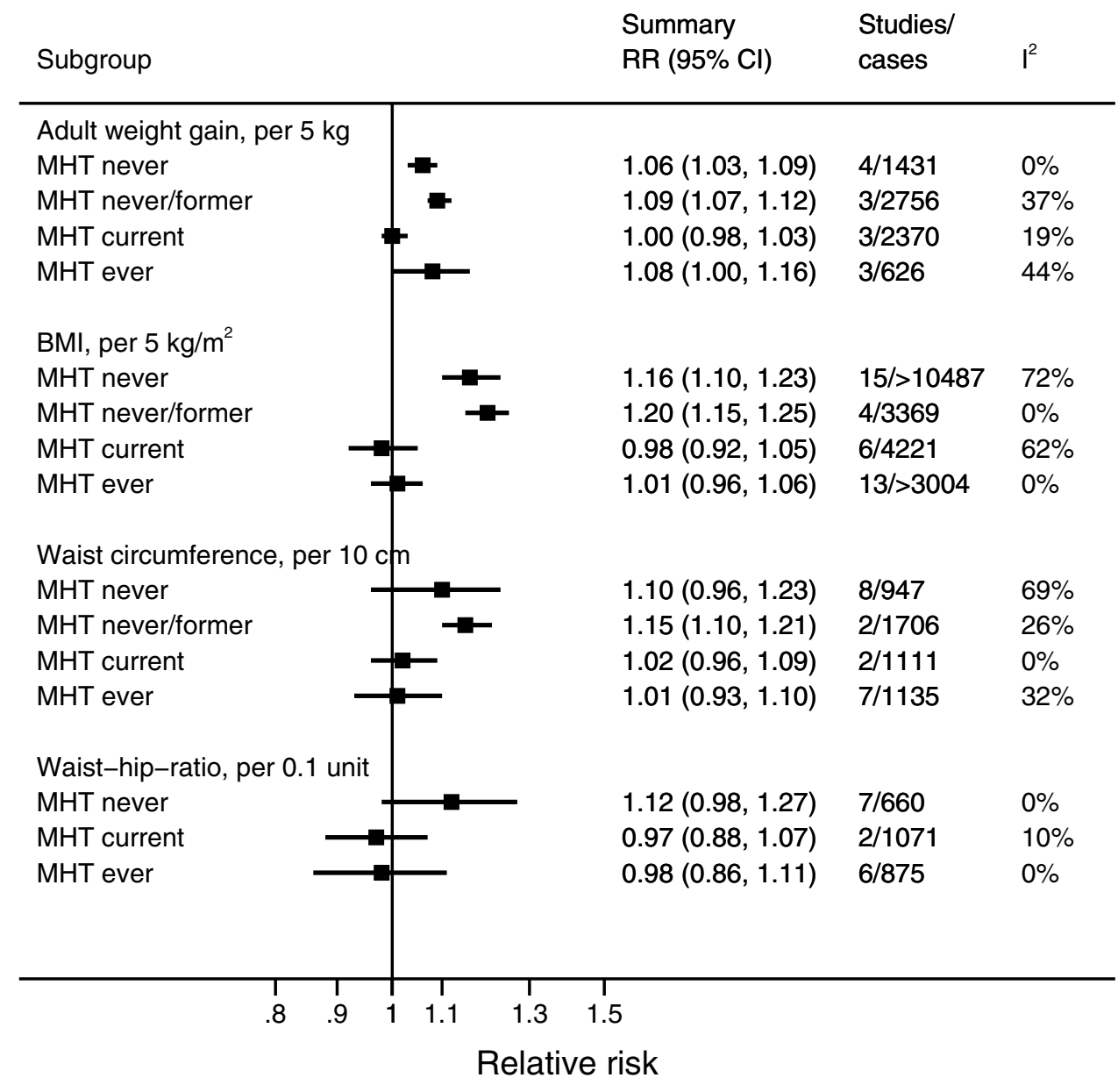

\section{Body mass index and postmenopausal breast cancer}

Greater BMI was significantly positively associated with postmenopausal breast cancer. The summary RR was 1.12 (95\% CI $1.10-1.15)$ per $5 \mathrm{~kg} / \mathrm{m}^{2}\left(I^{2}=76 \%, p\right.$ heterogeneity $<0.001$ ) (75 studies) (Figs. 3 and S21).

Study location may partially explain between-study heterogeneity ( $p$ for meta-regression $<0.001$ ). Asian studies [59, $86,112,158,174]$ showed an average stronger positive association than studies from Europe [46, 47, 49, 63, 66, 72, 79, $88,91,96,97,115,120,125,143,153,168,169,171,172]$, North America [44, 51, 56, 57, 75, 80, 81, 98, 100, 101, 136, 152, 159, 167, 171, 178], and Australia and New Zealand $[68,135]$ (Table S9). Positive associations were evident among never [56, 72, 130, 136, 143, 162, 171, 178], former [178], and never/former [41, 75, 85, 106] postmenopausal hormone users but not current $[41,75,85,106,177,178]$ or ever $[56,72,102,130,162,171]$ postmenopausal hormone users ( $p$ for meta-regression $=0.002)($ Figs. 4 and S25).

The associations were different between the HR subtypes, with positive associations observed for postmenopausal $\mathrm{ER}+[57,65,82,84,95,100,102,141,154], \mathrm{PR}+[50,95$, $102,154]$, and $\mathrm{ER}+\mathrm{PR}+[41,55,95,102,132,136,148$,
$156,161,177]$ breast cancers, and non-significant associations for ER- [57, 60, 65, 82, 95, 100, 102, 154], PR- [50, 95, 102, 154], ER-PR- [41, 55, 95, 102, 132, 136, 148, 156, 161, 177], ER+PR- [41, 55, 73, 102, 132, 156, 161], and ER-PR+ [73] breast cancers (Figs. 5 and S26-S27).

In non-linear analysis, the estimated RRs for women who were overweight $\left(27.5 \mathrm{~kg} / \mathrm{m}^{2}\right)$ and obese $\left(32.5 \mathrm{~kg} / \mathrm{m}^{2}\right)$ were 1.16 (95\% CI 1.10-1.22) and 1.29 (1.19-1.39), respectively, compared with women who were normal weight $(21.7 \mathrm{~kg} /$ $\left.\mathrm{m}^{2}\right)(p=0.31)$ (Fig. S28). Small study bias was detected $(p=0.04)$. Asymmetry in the funnel plot was driven by a few studies reporting stronger than the average positive association $[79,80,86,112,158,159,174]$. BMI was positively associated with postmenopausal breast cancer mortality (1.21, 1.15-1.28) (39 studies [48, 132, 140, 143, 179]) (Fig. S29).

\section{Adult weight gain and BMI gain and premenopausal and postmenopausal breast cancer}

Adult weight gain and BMI gain (from aged 18 years to study baseline) were not associated with premenopausal breast cancer ( 9 studies and 6 studies, respectively) (Figs. 3 
Fig. 5 Summary risk estimates of hormone receptor-defined postmenopausal breast cancer per unit increment of adiposity and weight change

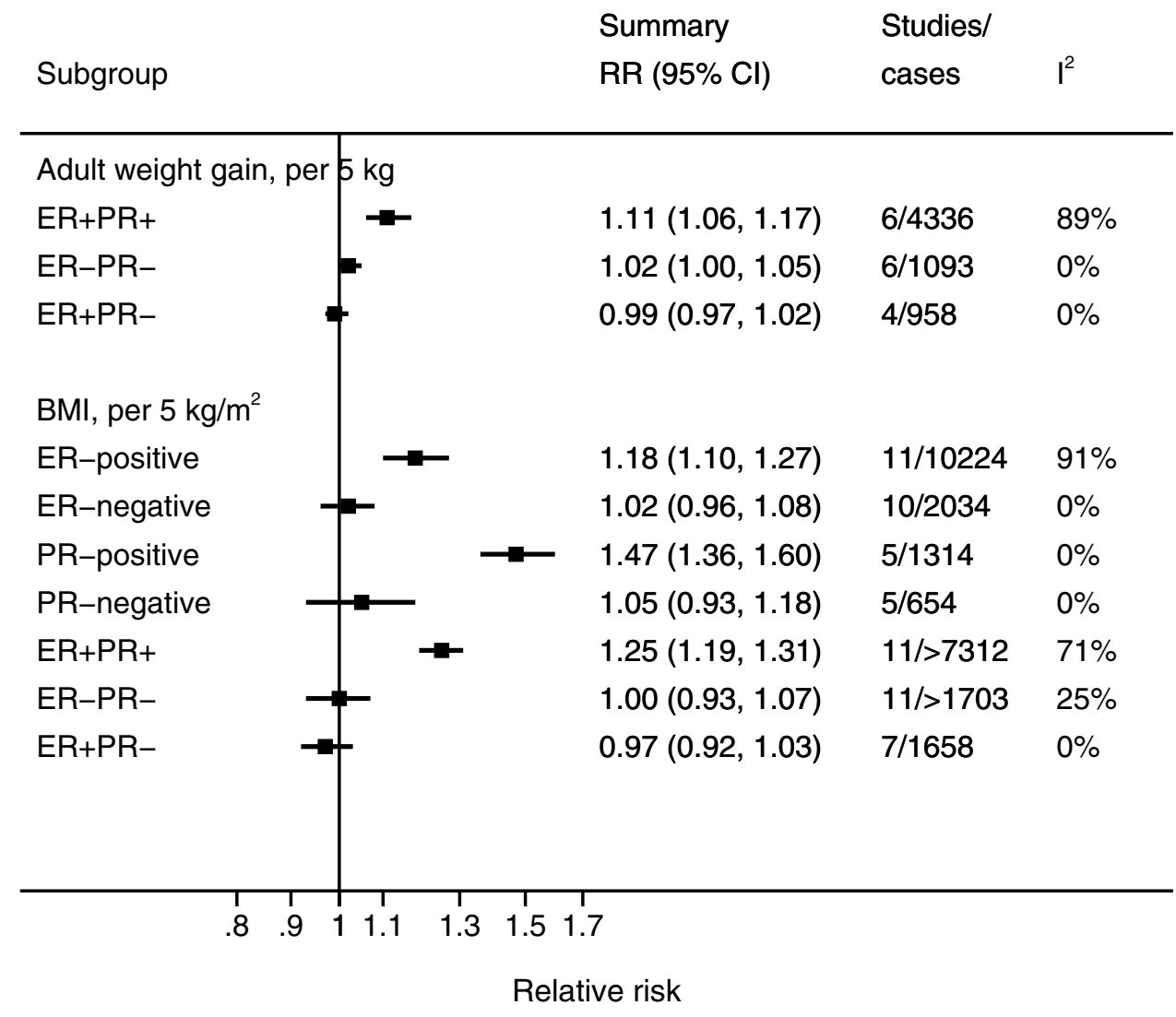

No deviation from linearity was detected $(p=0.75)$ (Fig. S35), but there was evidence of small study bias $(p=0.04)$. Asymmetry in the funnel plot was possibly driven by a small study [52] and Asian studies [99, 133] showing stronger positive associations.

\section{Adult weight loss and BMI loss and premenopausal and postmenopausal breast cancer}

Inverse associations were observed for both pre- and postmenopausal breast cancers when comparing any weight loss (of unknown intention, from aged 18 years to study baseline) with stable weight. The summary RRs were 0.85 (95\% CI $0.74-0.99 ; I^{2}=0 \%, p$ heterogeneity $=0.93$ ) ( 8 studies) and $0.90\left(0.81-0.99 ; I^{2}=24 \%, p\right.$ heterogeneity $=0.20)(14$ studies), respectively (Figs. 2 and S36). There was no clear pattern of differences between the subgroups (Table S12). Dose-response meta-analysis was possible for postmenopausal breast cancer (4 studies). The result was not significant (Fig. S37). Results similar to the main findings were observed in influence analyses, but the statistical significance was lost. There was no evidence of small study bias (Egger's test $p=0.26$ ). 
Waist and hip circumferences, and waist-to-hip ratio and premenopausal breast cancer

Higher waist circumference was not associated with premenopausal breast cancer. The per 10-cm increase summary RR was 0.99 (95\% CI $0.94-1.03 ; I^{2}=0 \%, p$ heterogeneity $=0.88)$ (7 studies) (Fig. 3); however, in studies further adjusted for BMI (4 studies [89, 94, 106, 177]), there was an average positive association (1.15, 1.05-1.26) (Fig. S38).

For hip circumference, there was a significant inverse association $\left(0.92,0.87-0.98\right.$ per $10 \mathrm{~cm} ; I^{2}=0 \%$, $p$ heterogeneity $=0.50)$ (4 studies) (Fig. 3); but a non-significant association in BMI adjusted studies (1.05, 0.80-1.36) (3 studies [89, 94, 106]) (Fig. S39).

For waist-to-hip ratio, there was a non-significant association $\left(1.05,0.98-1.13\right.$ per 0.1 unit; $I^{2}=14 \%, p$ heterogeneity $=0.31)(10$ studies $)($ Fig. 3); and a borderline positive association in BMI adjusted studies (1.14, 1.00-1.29) (7 studies [89, 94, 106, 112, 131, 159, 177]) (Fig. S40).

Results were similar across the subgroups (Tables S13-S15). Non-linear analyses showed no departure from linearity, but the $95 \%$ CIs were wide because of little data $(p \geq 0.07)$ (Figs. S41-S43). There was no indication of small study bias $(p=0.25)$.

\section{Waist and hip circumferences, and waist-to-hip ratio and postmenopausal breast cancer}

Postmenopausal breast cancer risk was significantly positively associated with all adiposity measures evaluated. The summary RRs were 1.11 (95\% CI 1.08-1.14; $I^{2}=44 \%, p$ heterogeneity $=0.04)$ per $10 \mathrm{~cm}$ of waist circumference $(23$ studies $), 1.06\left(1.04-1.09 ; I^{2}=0 \%, p\right.$ heterogeneity $\left.=0.48\right)$ per $10 \mathrm{~cm}$ of hip circumference (16 studies), and 1.10 $\left(1.05-1.16 ; I^{2}=60 \%, p\right.$ heterogeneity $\left.<0.001\right)$ per 0.1 unit of waist-to-hip ratio (29 studies) (Fig. 3). In BMI adjusted studies, the association was attenuated for waist circumference $(1.07,1.01-1.13)$ (7 studies [79, 82, 94, 98, 106, 154, 177]), lost statistical significance for hip circumference $(1.12,0.95-1.32)$ (3 studies [79, 94, 106]), and waist-to-hip ratio $(1.05,0.98-1.13)$ (8 studies $[79,94,106,112,131,154$, 159, 177]) (Figs. S44-S46).

The positive association was stronger in European [46, 79, 97, 145] and North American studies [41, 56, 76, 82, 94, 98, 101, 136] than Australian and New Zealand studies (10 studies, 1 publication [135]) ( $p$ for meta-regression $=0.04)$ (Table S13); and was more evident among never or former users $[41,56,79,82,130,136]$ than current or ever users $[41,56,79,130,177]$ of postmenopausal hormones ( $p$-values for meta-regression $\geq 0.06$ ) (Figs. 4 and S47-S48). There were no indications of non-linear relationship ( $p$-values $\geq 0.06$ ) (Figs. S49-S52) or small study bias ( $p$-values $\geq 0.25$ ).

\section{Quality of studies included in the meta-analyses}

Most studies used record linkage to ascertain cancer cases and met the required quality aspects (Figs. S53-56), and were considered average to good quality. Higher or lower risk of bias studies on average did not found significantly different associations in the subgroup meta-analyses (Tables S5-S17).

\section{Discussion}

\section{Summary of findings}

The present systematic literature review and meta-analysis demonstrates the complex associations between adulthood energy balance-related factors and breast cancer risk in preand postmenopausal women.

Higher physical activity, in particular recreational physical activity, was associated with reduced risk of pre- and postmenopausal breast cancer, although there were less data on premenopausal women. The risk reduction was observed at high levels similar to the prolonged moderate physical activity of 45 to 60 min daily suggested for weight maintenance [184]. Physical activity may operate through obesity-related biological pathways or mechanisms that involve immunity and defense [7, 185], which could explain the observed inverse associations for both postmenopausal ER+ and ER- breast cancers. Strenuous physical activity before menarche may delay the onset of menstruation and increase anovulatory cycles in young women [186]. In the present meta-analysis, significant inverse association was observed among normal weight women. It is unclear if the lack of association in overweight or obese women is due to low number of women with the required physical activity level or if any independent effect of physical activity is masked by excessive body adiposity. Previously, the National Cancer Institute Cohort Consortium (35,178 breast cancer cases overall) reported inverse associations in women of $\mathrm{BMI}<25$ and $\geq 25 \mathrm{~kg} / \mathrm{m}^{2}$, with no effect modification [187]. Confirmation is needed in pre- and postmenopausal women. Sedentary behavior, represented by sitting time, was associated with an increased risk of postmenopausal breast cancer. Excessive sitting reduces overall energy expenditure and contributes to obesity [188, 189], but could also be an independent risk factor for breast cancer [190].

Higher early adult BMI (ages 18-30 years) was inversely associated with both pre- and postmenopausal breast cancers. The results corroborate with the inverse association published recently by the Premenopausal Breast Cancer Collaborative Group of 19 cohort studies [191] (5 studies are in common with the present meta-analysis $[56,113,136,175$, 180]). The study also reported risk reductions for ER+ and 
ER- breast cancers in premenopausal women [191], which are potentially driven by estrogen-induced early breast differentiation [192] and slower pubertal growth [193] that may reduce the susceptibility to carcinogens in the breast tissue of young girls with higher adiposity.

Weight loss was inversely associated with pre- and postmenopausal breast cancer. The results were not robust, and the intentionality of weight loss and potential weight regain were largely not known in the studies. The present findings require further confirmations, although studies of stable weight loss and bariatric surgery have shown postmenopausal breast cancer risk reduction [70, 194, 195], and participants who lost weight or body fat in randomized controlled trials have demonstrated favorable changes in hormonal and metabolic profiles [196-198].

Weight gain (from aged 18 years to study baseline) and subsequent excessive body adiposity (total adiposity, assessed by BMI at study baseline; abdominal adiposity, assessed by waist circumference, and waist-to-hip ratio; and gluteo-femoral adiposity, assessed by hip circumference) consistently increased the risk of breast cancer in postmenopausal women. Non-linear analyses did not reveal any threshold, indicating any weight gain after early adult years may lead to increased risk. The associations were more evident for HR+ but not HR- postmenopausal breast cancers; and among never but not current users of postmenopausal hormones, probably because exogenous estrogens, a strong risk factor of postmenopausal breast cancer [199], have masked the effect of the hormones synthesized in adipose tissue. Recent publications reported largely supportive results. These included the different age-specific associations with baseline BMI for the risk of luminal-like and triple-negative breast cancers reported by the National Cancer Institute Cohort Consortium (9 cohorts) [200], and the strong positive associations between different adiposity measures and breast cancer risk in long-term postmenopausal women reported by the UK Biobank Prospective Cohort Study [201].

The evidence was less consistent in premenopausal women. In the present meta-analysis, we observed no association with adult weight gain, but weight gain between 40 and 50 years has been reported to increase premenopausal breast cancer risk [72]. Since middle age is a period when more fat is deposited viscerally [202], it is possible that timing, duration, as well as location of fat deposition are important factors for breast cancer development. Higher adult BMI (study baseline) was inversely associated with breast cancer risk in premenopausal women, although there was a lack of consistency across the study results. One possible explanation is the positive association observed in Asian studies $[112,174]$. Asian women tend to be more prone to visceral fat accumulation than their Western counterparts [203], but further replication of the result is needed. In terms of abdominal obesity, we observed non-significant associations that were reverted to positive associations in studies accounting for total adiposity; since total and abdominal adiposity are highly correlated [41, 145, 159, 165], the suggested independent effect requires confirmation. There were no significant associations for HR-defined premenopausal breast cancers, but the meta-analyses included few studies.

Mechanistically, increased expression of aromatase in adipose tissue of postmenopausal women with obesity increases conversion of androgens to estrogens that induce tumor cell proliferation and inhibit apoptosis [204, 205]; whereas lowered concentrations of progesterone in premenopausal women with obesity mitigate estrogen-induced proliferation in breast epithelial cells [206], albeit inconsistent findings on progesterone and breast cancer [207-209]. Studies on gene expression patterns in breast tissue have shown that as body weight increases, there is increased breast cancer cell proliferation in postmenopausal women but decreased proliferation in premenopausal women [210]. Abdominal obesity is frequently associated with insulin resistance and hyperinsulinemia [211, 212]. Insulin and insulin-like growth factor-I are mitogenic. Insulin also inhibits sex hormonebinding globulin synthesis, leading to higher concentrations of free oestradiol [205]. Other proposed mechanisms that link obesity to breast cancer include increased concentrations of proinflammatory cytokines and leptin that induce aromatization and reduced concentrations of adiponectin that has anti-inflammatory and insulin-sensitizing ability [205, 213-215].

Our findings are generally in agreement with those of published umbrella reviews of the literature evidence on physical activity and adiposity with cancer risk [216-218], but are opposite to the results of Mendelian randomization (MR) studies. Recent publications from large-sized MR studies reported inverse associations with genetically predicted adiposity for the risk of breast cancer, overall [219] and in premenopausal [220-222] and postmenopausal women [220, 222], which were not shown in an earlier small study [47]. One possible explanation is that genetically predicted adiposity may be more closely related to early life adiposity than later life adiposity that is largely influenced by the environment. One MR study provided causal evidence that higher childhood adiposity reduces breast cancer risk [219].

\section{Study limitations}

Several limitations in the present review require discussion. There may be some level of misclassification of cancer as pre- or postmenopausal depending on whether the required information was taken at study baseline or cancer diagnosis; however, subgroup meta-analyses by timing of classification mostly did not show significantly different associations. 
Premenopausal breast cancer studies that used baseline information on average found an inverse association with adult BMI, opposite to the positive association in postmenopausal studies.

The association with physical activity may have been underestimated due to measurement error, as frequency, intensity, and type of activity were poorly characterized in most studies. Attenuation of the associations due to regression dilution is possible as most studies had long follow-up ( $\geq 10$ years) and collected information at baseline. Recall or other biases in weight change and weight at early age are also possible. While BMI-a practical measure of total adiposity-is predictive of health outcomes on a population level, it does not reflect fat distribution or differentiates lean from fat mass that varies across women of different age and ethnicity [223].

Data on pre- and postmenopausal hormone receptordefined breast cancers were limited. Information on type of postmenopausal hormone use was not available for metaanalysis. A few studies did not report data sufficient for the meta-analysis [224-230]; nevertheless, most excluded studies reported concordant findings with the meta-analyses.

\section{Strength of the study and future research}

The present systematic literature review is extensive and comprehensive, in that all known existing scientific evidence from observational cohort studies-a design that is less prone to recall and selection biases than case-control studies [9]—on different domains of physical activity, sedentary behavior, adiposity measures, and weight change in different periods of adulthood in relation to breast cancer risk by menopausal status and hormone receptor subtype were summarized. Most meta-analyses comprised more than 900 breast cancer cases from at least three cohort studies that were of average to good quality.

With the accumulated evidence, we were able to explore the magnitude and the shape of the associations. Nevertheless, more longitudinal studies with repeated exposure assessments along the life course are needed, in women across all age range, and from different ethnic/racial groups who may have different risk patterns. Improved assessments for better quantification and characterization of exposure factors are needed, to evaluate their independent and joint effects on breast cancer development. Also, more studies are needed to clarify the different associations in molecular and clinical breast cancer subgroups. Randomized controlled trials, in particular weight loss trials and physical activity trials, are needed to provide definitive evidence for effective interventions to prevent breast cancer.
In conclusion, physical activity reduces breast cancer risk in both pre- and postmenopausal women, whereas factors reflecting energy imbalance influence the risk differently along the life course of the women. Although higher adiposity at early adulthood may reduce pre- and postmenopausal breast cancer risk, weight gain and excessive adiposity later in life increase the risk, consistently in postmenopausal women and evidently for HR + but not for HR- postmenopausal breast cancers. Under precautionary principle, women should aim to be physically active (at least $150 \mathrm{~min} /$ week) and follow a lifestyle that leads to healthy body weight (BMI $18.5-24.9 \mathrm{~kg} / \mathrm{m}^{2}$ ) for breast cancer prevention. Only about $25 \%$ of the public recognize the link between obesity and cancer [231]. Therefore, collective effort-driven by public health policies [232] - is needed to promote healthy lifestyles for cancer prevention.

Acknowledgments We thank the systematic literature review team at the National Cancer Institute Milan and the World Cancer Research Fund International Continuous Update Project team members: Rita Vieira, Louise Abela, Snieguole Vingeliene, Neesha Nanu, Margarita Cariolou, Deborah Navarro Rosenblatt, Jakub Sobiecki, Leila Abar, Rosa Lau, Dagfinn Aune, and Elli Polemiti at Imperial College London for their contribution to data extraction. We thank database managers Rui Vieira and Christophe Stevens for implementing and updating the WCRF CUP database.

Author contributions TN is the principal investigator of the Continuous Update Project at Imperial College London and wrote the protocol and implemented the study. RV and CS developed and managed the database for the Continuous Update Project. DSMC, RV, and LA did the literature search and study selections. DSMC, RV, LA, SV, NN, MC, DNR, JS, LA, RL, DA, and EP did the data extraction. DSMC checked, analyzed, and interpreted the data. DCG was statistical adviser. AMT and EVB were panel members of the Continuous Update Project and advised on the interpretation of the review. DSMC drafted the original manuscript and all authors revised the manuscript. DSMC is the guarantor and has full access to all the data and takes responsibility for the integrity of the data and the accuracy of the data analysis.

Funding This work was supported by the World Cancer Research Fund International (https://www.wcrf-uk.org/) [Grant Number 2007/ SP01]. The funders of this study had no role in the decisions about the design and conduct of the study; collection, management, analysis, or interpretation of the data; or the preparation, review, or approval of the manuscript. The views expressed in this review are the opinions of the authors. They may not represent the views of the World Cancer Research Fund International/American Institute for Cancer Research and may differ from those in future updates of the evidence related to food, nutrition, physical activity, and cancer prevention.

\section{Compliance with ethical standards}

Conflict of interest Teresa Norat, Doris S.M. Chan, Leila Abar; Margarita Cariolou, and Neesha Nanu are supported by the World Cancer Research Fund International. Anne McTiernan has received research grant from the Breast Cancer Research Foundation. Darren C. Greenwood and Elisa V. Bandera declare that they have no conflicts of interest. 
Open Access This article is distributed under the terms of the Creative Commons Attribution 4.0 International License (http://creativeco mmons.org/licenses/by/4.0/), which permits unrestricted use, distribution, and reproduction in any medium, provided you give appropriate credit to the original author(s) and the source, provide a link to the Creative Commons license, and indicate if changes were made.

\section{References}

1. Ferlay J, Ervik M, Lam F et al (2018) Global cancer observatory: cancer today. International Agency for Research on Cancer, Lyon. Available at https://gco.iarc.fr/today. Accessed 18 Feb 2019

2. International Agency for Research on Cancer (2016) IARC Handbooks of Cancer Prevention, Volume 15, Breast Cancer Screening. IARC, Lyon

3. Vineis P, Wild CP (2014) Global cancer patterns: causes and prevention. Lancet 383(9916):549-557

4. Finucane MM, Stevens GA, Cowan MJ, Danaei G, Lin JK, Paciorek CJ et al (2011) National, regional, and global trends in body-mass index since 1980: systematic analysis of health examination surveys and epidemiological studies with 960 country-years and 9.1 million participants. Lancet 377(9765):557-567

5. Ng M, Fleming T, Robinson M, Thomson B, Graetz N, Margono C et al (2014) Global, regional, and national prevalence of overweight and obesity in children and adults during 19802013: a systematic analysis for the Global Burden of Disease Study 2013. Lancet 384(9945):766-781

6. Romieu I, Dossus L, Barquera S, Blottiere HM, Franks PW, Gunter M et al (2017) Energy balance and obesity: what are the main drivers? Cancer Causes Control 28(3):247-258

7. McTiernan A (2008) Mechanisms linking physical activity with cancer. Nat Rev Cancer 8(3):205-211

8. World Cancer Research Fund/American Institute for Cancer Research (2018) Diet, nutrition, physical activity and cancer: a global perspective. Continuous Update Project Expert Report 2018. Available at http://www.dietandcancerreport.org. Accessed 29 Aug 2019

9. World Cancer Research Fund/American Institute for Cancer Research (2007) Food, nutrition, physical activity, and the prevention of cancer: a global perspective. AICR, Washington DC

10. Catsburg C, Miller AB, Rohan TE (2014) Adherence to cancer prevention guidelines and risk of breast cancer. Int $\mathrm{J}$ Cancer 135(10):2444-2452

11. Harris HR, Bergkvist L, Wolk A (2016) Adherence to the World Cancer Research Fund/American Institute for Cancer Research recommendations and breast cancer risk. Int J Cancer 138(11):2657-2664

12. Hastert TA, Beresford SA, Patterson RE, Kristal AR, White E (2013) Adherence to WCRF/AICR cancer prevention recommendations and risk of postmenopausal breast cancer. Cancer Epidemiol Biomarkers Prev 22(9):1498-1508

13. Makarem N, Lin Y, Bandera EV, Jacques PF, Parekh N (2015) Concordance with World Cancer Research Fund/American Institute for Cancer Research (WCRF/AICR) guidelines for cancer prevention and obesity-related cancer risk in the Framingham Offspring cohort (1991-2008). Cancer Causes Control 26(2):277-286

14. Nomura SJ, Dash C, Rosenberg L, Yu J, Palmer JR, AdamsCampbell LL (2016) Adherence to diet, physical activity and body weight recommendations and breast cancer incidence in the Black Women's Health Study. Int J Cancer 139(12):2738-2752

15. Nomura SJ, Inoue-Choi M, Lazovich D, Robien K (2016) WCRF/AICR recommendation adherence and breast cancer incidence among postmenopausal women with and without non-modifiable risk factors. Int J Cancer 138(11):2602-2615

16. Romaguera D, Vergnaud AC, Peeters PH, van Gils CH, Chan DS, Ferrari P et al (2012) Is concordance with World Cancer Research Fund/American Institute for Cancer Research guidelines for cancer prevention related to subsequent risk of cancer? Results from the EPIC study. Am J Clin Nutr 96(1):150-163

17. Lavalette C, Adjibade M, Srour B, Sellem L, Fiolet T, Hercberg $S$ et al (2018) Cancer-specific and general nutritional scores and cancer risk: results from the prospective NutriNet-Sante cohort. Cancer Res 78(15):4427-4435

18. Lohse T, Faeh D, Bopp M, Rohrmann S (2016) Adherence to the cancer prevention recommendations of the World Cancer Research Fund/American Institute for Cancer Research and mortality: a census-linked cohort. Am J Clin Nutr 104(3):678-685

19. Vergnaud AC, Romaguera D, Peeters PH, van Gils CH, Chan DS, Romieu I et al (2013) Adherence to the World Cancer Research Fund/American Institute for Cancer Research guidelines and risk of death in Europe: results from the European Prospective Investigation into Nutrition and Cancer cohort study1,4. Am J Clin Nutr 97(5):1107-1120

20. Inoue-Choi M, Robien K, Lazovich D (2013) Adherence to the WCRF/AICR guidelines for cancer prevention is associated with lower mortality among older female cancer survivors. Cancer Epidemiol Biomarkers Prev 22(5):792-802

21. World Cancer Research Fund/American Institute for Cancer Research: Continuous Update Project (CUP) (2016). Available at http://www.wcrf-uk.org/uk/our-research/our-continuous-updat e-project. Accessed 18 Feb 2019

22. Colditz GA, Bohlke K, Berkey CS (2014) Breast cancer risk accumulation starts early: prevention must also. Breast Cancer Res Treat 145(3):567-579

23. Munsell MF, Sprague BL, Berry DA, Chisholm G, TrenthamDietz A (2014) Body mass index and breast cancer risk according to postmenopausal estrogen-progestin use and hormone receptor status. Epidemiol Rev 36:114-136

24. Barnard ME, Boeke CE (1856) Tamimi RM (2015) Established breast cancer risk factors and risk of intrinsic tumor subtypes. Biochim Biophys Acta 1:73-85

25. Bandera EV, Chandran U, Hong CC, Troester MA, Bethea TN, Adams-Campbell LL et al (2015) Obesity, body fat distribution, and risk of breast cancer subtypes in African American women participating in the AMBER Consortium. Breast Cancer Res Treat 150(3):655-666

26. Gong Z, Hong CC, Bandera EV, Adams-Campbell LL, Troester MA, Park SY et al (2016) Vigorous physical activity and risk of breast cancer in the African American breast cancer epidemiology and risk consortium. Breast Cancer Res Treat 159(2):347-356

27. DerSimonian R, Laird N (1986) Meta-analysis in clinical trials. Control Clin Trials 7(3):177-188

28. Vingeliene S, Chan DSM, Vieira AR, Polemiti E, Stevens C, Abar L et al (2017) An update of the WCRF/AICR systematic literature review and meta-analysis on dietary and anthropometric factors and esophageal cancer risk. Ann Oncol 28(10):2409-2419

29. Abar L, Vieira AR, Aune D, Sobiecki JG, Vingeliene S, Polemiti E et al (2018) Height and body fatness and colorectal cancer risk: an update of the WCRF-AICR systematic review of published prospective studies. Eur J Nutr 57(5):1701-1720

30. Abar L, Sobiecki JG, Cariolou M, Nanu N, Vieira AR, Stevens $\mathrm{C}$ et al (2019) Body size and obesity during adulthood, and risk of lympho-hematopoietic cancers: an update of the WCRF-AICR systematic review of published prospective studies. Ann Oncol 7:528-541

31. Chan DS, Vieira AR, Aune D, Bandera EV, Greenwood DC, McTiernan A et al (2014) Body mass index and survival in 
women with breast cancer-systematic literature review and metaanalysis of 82 follow-up studies. Ann Oncol 25(10):1901-1914

32. Orsini N, Bellocco R, Greenland S (2006) Generalized least squares for trend estimation of summarized dose-response data. Stata J 6:40-57

33. Greenland S, Longnecker MP (1992) Methods for trend estimation from summarized dose-response data, with applications to meta-analysis. Am J Epidemiol 135(11):1301-1309

34. Aune D, Greenwood DC, Chan DS, Vieira R, Vieira AR, Navarro Rosenblatt DA et al (2012) Body mass index, abdominal fatness and pancreatic cancer risk: a systematic review and non-linear dose-response meta-analysis of prospective studies. Ann Oncol 23(4):843-852

35. Bekkering GE, Harris RJ, Thomas S, Mayer AM, Beynon R, Ness AR et al (2008) How much of the data published in observational studies of the association between diet and prostate or bladder cancer is usable for meta-analysis? Am J Epidemiol 167(9):1017-1026

36. Higgins JP, Thompson SG (2002) Quantifying heterogeneity in a meta-analysis. Stat Med 21(11):1539-1558

37. Stram DO (1996) Meta-analysis of published data using a linear mixed-effects model. Biometrics 52(2):536-544

38. Egger M, Davey SG, Schneider M, Minder C (1997) Bias in meta-analysis detected by a simple, graphical test. BMJ 315(7109):629-634

39. Jackson D, White IR, Thompson SG (2010) Extending DerSimonian and Laird's methodology to perform multivariate random effects meta-analyses. Stat Med 29(12):1282-1297

40. Orsini N, Li R, Wolk A, Khudyakov P, Spiegelman D (2012) Meta-analysis for linear and nonlinear dose-response relations: examples, an evaluation of approximations, and software. Am J Epidemiol 175(1):66-73

41. Ahn J, Schatzkin A, Lacey JV Jr, Albanes D, Ballard-Barbash R, Adams KF et al (2007) Adiposity, adult weight change, and postmenopausal breast cancer risk. Arch Intern Med 167(19):2091-2102

42. Albanes D, Blair A, Taylor PR (1989) Physical activity and risk of cancer in the NHANES I population. Am J Public Health 79(6):744-750

43. Alsaker MD, Janszky I, Opdahl S, Vatten LJ, Romundstad PR (2013) Weight change in adulthood and risk of postmenopausal breast cancer: the HUNT study of Norway. Br J Cancer 109(5):1310-1317

44. Andreotti G, Hou L, Beane Freeman LE, Mahajan R, Koutros S, Coble J et al (2010) Body mass index, agricultural pesticide use, and cancer incidence in the Agricultural Health Study cohort. Cancer Causes Control 21(11):1759-1775

45. Bardia A, Hartmann LC, Vachon CM, Vierkant RA, Wang AH, Olson JE et al (2006) Recreational physical activity and risk of postmenopausal breast cancer based on hormone receptor status. Arch Intern Med 166(22):2478-2483

46. Bellocco R, Marrone G, Ye W, Nyren O, Adami HO, Mariosa D et al (2016) A prospective cohort study of the combined effects of physical activity and anthropometric measures on the risk of post-menopausal breast cancer. Eur J Epidemiol 31(4):395-404

47. Benn M, Tybjaerg-Hansen A, Smith GD, Nordestgaard BG (2016) High body mass index and cancer risk-a Mendelian randomisation study. Eur J Epidemiol 31(9):879-892

48. Bessonova L, Marshall SF, Ziogas A, Largent J, Bernstein L, Henderson KD et al (2011) The association of body mass index with mortality in the California Teachers Study. Int J Cancer 129(10):2492-2501

49. Bhaskaran K, Douglas I, Forbes H, Santos-Silva I, Leon DA, Smeeth L (2014) Body-mass index and risk of 22 specific cancers: a population-based cohort study of 5.24 million UK adults. Lancet 384(9945):755-765
50. Borgquist S, Jirstrom K, Anagnostaki L, Manjer J, Landberg G (2009) Anthropometric factors in relation to different tumor biological subgroups of postmenopausal breast cancer. Int J Cancer 124(2):402-411

51. Brasky TM, Lampe JW, Potter JD, Patterson RE, White E (2010) Specialty supplements and breast cancer risk in the VITamins And Lifestyle (VITAL) Cohort. Cancer Epidemiol Biomarkers Prev 19(7):1696-1708

52. Breslow RA, Ballard-Barbash R, Munoz K, Graubard BI (2001) Long-term recreational physical activity and breast cancer in the National Health and Nutrition Examination Survey I epidemiologic follow-up study. Cancer Epidemiol Biomarkers Prev 10(7):805-808

53. Brinton LA, Smith L, Gierach GL, Pfeiffer RM, Nyante SJ, Sherman ME et al (2014) Breast cancer risk in older women: results from the NIH-AARP Diet and Health Study. Cancer Causes Control 25(7):843-857

54. Burton A, Martin R, Galobardes B, Davey SG, Jeffreys M (2010) Young adulthood body mass index and risk of cancer in later adulthood: historical cohort study. Cancer Causes Control 21(12):2069-2077

55. Canchola AJ, Anton-Culver H, Bernstein L, Clarke CA, Henderson $\mathrm{K}$, Ma $\mathrm{H}$ et al (2012) Body size and the risk of postmenopausal breast cancer subtypes in the California Teachers Study cohort. Cancer Causes Control 23:473-485

56. Catsburg C, Kirsh VA, Soskolne CL, Kreiger N, Bruce E, Ho T et al (2014) Associations between anthropometric characteristics, physical activity, and breast cancer risk in a Canadian cohort. Breast Cancer Res Treat 145(2):545-552

57. Cecchini RS, Costantino JP, Cauley JA, Cronin WM, Wickerham DL, Land SR et al (2012) Body mass index and the risk for developing invasive breast cancer among high-risk women in NSABP P-1 and STAR breast cancer prevention trials. Cancer Prev Res (Phila) 5(4):583-592

58. Chang SC, Ziegler RG, Dunn B, Stolzenberg-Solomon R, Lacey JV Jr, Huang WY et al (2006) Association of energy intake and energy balance with postmenopausal breast cancer in the prostate, lung, colorectal, and ovarian cancer screening trial. Cancer Epidemiol Biomarkers Prev 15(2):334-341

59. Chen MJ, Wu WY, Yen AM, Fann JC, Chen SL, Chiu SY et al (2016) Body mass index and breast cancer: analysis of a nationwide population-based prospective cohort study on 1,393,985 Taiwanese women. Int J Obes (Lond) 40(3):524-530

60. Chlebowski RT, Anderson GL, Lane DS, Aragaki AK, Rohan T, Yasmeen S et al (2007) Predicting risk of breast cancer in postmenopausal women by hormone receptor status. J Natl Cancer Inst 99(22):1695-1705

61. Cohen SS, Matthews CE, Bradshaw PT, Lipworth L, Buchowski MS, Signorello LB et al (2013) Sedentary behavior, physical activity, and likelihood of breast cancer among Black and White women: a report from the Southern Community Cohort Study. Cancer Prev Res (Phila) 6(6):566-576

62. Colditz GA, Feskanich D, Chen WY, Hunter DJ, Willett WC (2003) Physical activity and risk of breast cancer in premenopausal women. Br J Cancer 89(5):847-851

63. Couto E, Sandin S, Lof M, Ursin G, Adami HO, Weiderpass E (2013) Mediterranean dietary pattern and risk of breast cancer. PLoS ONE 8(2):e55374

64. Dallal CM, Sullivan-Halley J, Ross RK, Wang Y, Deapen D, Horn-Ross PL et al (2007) Long-term recreational physical activity and risk of invasive and in situ breast cancer: the California teachers study. Arch Intern Med 167(4):408-415

65. Dartois L, Fagherazzi G, Baglietto L, Boutron-Ruault MC, Delaloge S, Mesrine S et al (2016) Proportion of premenopausal and postmenopausal breast cancers attributable to known 
risk factors: Estimates from the E3N-EPIC cohort. Int J Cancer 138(10):2415-2427

66. De Stavola BL, Wang DY, Allen DS, Giaconi J, Fentiman IS, Reed MJ et al (1993) The association of height, weight, menstrual and reproductive events with breast cancer: results from two prospective studies on the island of Guernsey (United Kingdom). Cancer Causes Control 4(4):331-340

67. Dirx MJ, Voorrips LE, Goldbohm RA, van den Brandt PA (2001) Baseline recreational physical activity, history of sports participation, and postmenopausal breast carcinoma risk in the Netherlands Cohort Study. Cancer 92(6):1638-1649

68. Dite GS, Macinnis RJ, Bickerstaffe A, Dowty JG, Milne RL, Antoniou AC et al (2017) Testing for gene-environment interactions using a prospective family cohort design: body mass index in early and later adulthood and risk of breast cancer. Am J Epidemiol 185(6):487-500

69. Ekenga CC, Parks CG, Sandler DP (2015) A prospective study of occupational physical activity and breast cancer risk. Cancer Causes Control 26(12):1779-1789

70. Eliassen AH, Colditz GA, Rosner B, Willett WC, Hankinson SE (2006) Adult weight change and risk of postmenopausal breast cancer. JAMA 296(2):193-201

71. Eliassen AH, Hankinson SE, Rosner B, Holmes MD, Willett WC (2010) Physical activity and risk of breast cancer among postmenopausal women. Arch Intern Med 170(19):1758-1764

72. Emaus MJ, van Gils CH, Bakker MF, Bisschop CN, Monninkhof EM, Bueno-de-Mesquita HB et al (2014) Weight change in middle adulthood and breast cancer risk in the EPIC-PANACEA study. Int J Cancer 135(12):2887-2899

73. Fagherazzi G, Chabbert-Buffet N, Fabre A, Guillas G, BoutronRuault MC, Mesrine S et al (2012) Hip circumference is associated with the risk of premenopausal ER-/PR- breast cancer. Int J Obes (Lond) 36(3):431-439

74. Feigelson HS, Patel AV, Teras LR, Gansler T, Thun MJ, Calle EE (2006) Adult weight gain and histopathologic characteristics of breast cancer among postmenopausal women. Cancer 107(1):12-21

75. Feigelson HS, Jonas CR, Teras LR, Thun MJ, Calle EE (2004) Weight gain, body mass index, hormone replacement therapy, and postmenopausal breast cancer in a large prospective study. Cancer Epidemiol Biomarkers Prev 13(2):220-224

76. Folsom AR, Kushi LH, Anderson KE, Mink PJ, Olson JE, Hong $\mathrm{CP}$ et al (2000) Associations of general and abdominal obesity with multiple health outcomes in older women: the Iowa Women's Health Study. Arch Intern Med 160(14):2117-2128

77. Folsom AR, Kaye SA, Prineas RJ, Potter JD, Gapstur SM, Wallace RB (1990) Increased incidence of carcinoma of the breast associated with abdominal adiposity in postmenopausal women. Am J Epidemiol 131(5):794-803

78. Fournier A, Dos SG, Guillas G, Bertsch J, Duclos M, BoutronRuault MC et al (2014) Recent recreational physical activity and breast cancer risk in postmenopausal women in the E3N cohort. Cancer Epidemiol Biomarkers Prev 23(9):1893-1902

79. Freisling H, Arnold M, Soerjomataram I, O'Doherty MG, Ordonez-Mena JM, Bamia C et al (2017) Comparison of general obesity and measures of body fat distribution in older adults in relation to cancer risk: meta-analysis of individual participant data of seven prospective cohorts in Europe. Br J Cancer 116(11):1486-1497

80. Galanis DJ, Kolonel LN, Lee J, Le ML (1998) Anthropometric predictors of breast cancer incidence and survival in a multiethnic cohort of female residents of Hawaii United states. Cancer Causes Control 9(2):217-224

81. Gaudet MM, Falk RT, Gierach GL, Lacey JV Jr, Graubard BI, Dorgan JF et al (2010) Do adipokines underlie the association between known risk factors and breast cancer among a cohort of United States women? Cancer Epidemiol 34(5):580-586

82. Gaudet MM, Carter BD, Patel AV, Teras LR, Jacobs EJ, Gapstur SM (2014) Waist circumference, body mass index, and postmenopausal breast cancer incidence in the Cancer Prevention Study-II Nutrition Cohort. Cancer Causes Control 25(6):737-745

83. George SM, Irwin ML, Matthews CE, Mayne ST, Gail MH, Moore SC et al (2010) Beyond recreational physical activity: examining occupational and household activity, transportation activity, and sedentary behavior in relation to postmenopausal breast cancer risk. Am J Public Health 100(11):2288-2295

84. Grenier D, Cooke AL, Lix L, Metge C, Lu H, Leslie WD (2011) Bone mineral density and risk of postmenopausal breast cancer. Breast Cancer Res Treat 126(3):679-686

85. Gunter MJ, Hoover DR, Yu H, Wassertheil-Smoller S, Rohan TE, Manson JE et al (2009) Insulin, insulin-like growth factor-I, and risk of breast cancer in postmenopausal women. J Natl Cancer Inst 101(1):48-60

86. Guo L, Li N, Wang G, Su K, Li F, Yang L et al (2014) Body mass index and cancer incidence: a prospective cohort study in northern China. Zhonghua Liu Xing Bing Xue Za Zhi 35(3):231-236

87. Han X, Stevens J, Truesdale KP, Bradshaw PT, KucharskaNewton A, Prizment AE et al (2014) Body mass index at early adulthood, subsequent weight change and cancer incidence and mortality. Int J Cancer 135(12):2900-2909

88. Harlid S, Butt S, Ivarsson MI, Eyfjord JE, Lenner P, Manjer $\mathrm{J}$ et al (2012) Interactive effect of genetic susceptibility with height, body mass index, and hormone replacement therapy on the risk of breast cancer. BMC Womens Health 12:17

89. Harris HR, Willett WC, Terry KL, Michels KB (2011) Body fat distribution and risk of premenopausal breast cancer in the Nurses' Health Study II. J Natl Cancer Inst 103(3):273-278

90. Hildebrand JS, Gapstur SM, Campbell PT, Gaudet MM, Patel AV (2013) Recreational physical activity and leisure-time sitting in relation to postmenopausal breast cancer risk. Cancer Epidemiol Biomark Prev 22(10):1906-1912

91. Horn J, Alsaker MD, Opdahl S, Engstrom MJ, Tretli S, Haugen OA et al (2014) Anthropometric factors and risk of molecular breast cancer subtypes among postmenopausal Norwegian women. Int J Cancer 135(11):2678-2686

92. Howard RA, Leitzmann MF, Linet MS, Freedman DM (2009) Physical activity and breast cancer risk among pre- and postmenopausal women in the U.S. Radiologic Technologists cohort. Cancer Causes Control 20(3):323-333

93. Huang Z, Hankinson SE, Colditz GA, Stampfer MJ, Hunter DJ, Manson JE et al (1997) Dual effects of weight and weight gain on breast cancer risk. JAMA 278(17):1407-1411

94. Huang Z, Willett WC, Colditz GA, Hunter DJ, Manson JE, Rosner B et al (1999) Waist circumference, waist:hip ratio, and risk of breast cancer in the Nurses' Health Study. Am J Epidemiol 150(12):1316-1324

95. Iwasaki M, Otani T, Inoue M, Sasazuki S, Tsugane S (2007) Body size and risk for breast cancer in relation to estrogen and progesterone receptor status in Japan. Ann Epidemiol 17(4):304-312

96. Johnsson A, Broberg P, Johnsson A, Tornberg AB, Olsson H (2017) Occupational sedentariness and breast cancer risk. Acta Oncol 56(1):75-80

97. Kaaks R, Van Noord PA, Den I, Peeters PH, Riboli E, Grobbee DE (1998) Breast-cancer incidence in relation to height, weight and body-fat distribution in the Dutch "DOM" cohort. Int J Cancer 76(5):647-651

98. Kabat GC, Xue X, Kamensky V, Lane D, Bea JW, Chen C et al (2015) Risk of breast, endometrial, colorectal, and renal cancers in postmenopausal women in association with a body shape 
index and other anthropometric measures. Cancer Causes Control 26(2):219-229

99. Kawai M, Minami Y, Kuriyama S, Kakizaki M, Kakugawa Y, Nishino $Y$ et al (2010) Adiposity, adult weight change and breast cancer risk in postmenopausal Japanese women: the Miyagi Cohort Study. Br J Cancer 103(9):1443-1447

100. Kerlikowske K, Walker R, Miglioretti DL, Desai A, BallardBarbash R, Buist DS (2008) Obesity, mammography use and accuracy, and advanced breast cancer risk. J Natl Cancer Inst 100(23):1724-1733

101. Krebs EE, Taylor BC, Cauley JA, Stone KL, Bowman PJ, Ensrud KE (2006) Measures of adiposity and risk of breast cancer in older postmenopausal women. J Am Geriatr Soc 54(1):63-69

102. Krishnan K, Bassett JK, Macinnis RJ, English DR, Hopper JL, McLean C et al (2013) Associations between weight in early adulthood, change in weight, and breast cancer risk in postmenopausal women. Cancer Epidemiol Biomark Prev 22(8):1409-1416

103. Kwan K, Chlebowski RT, McTiernan A, Rodabough RJ, La Monte MJ, Martin LW et al (2014) Walking speed, physical activity, and breast cancer in postmenopausal women. Eur $\mathbf{J}$ Cancer Prev 23(1):49-52

104. Lacey JV Jr, Kreimer AR, Buys SS, Marcus PM, Chang SC, Leitzmann MF et al (2009) Breast cancer epidemiology according to recognized breast cancer risk factors in the Prostate, Lung, Colorectal and Ovarian (PLCO) Cancer Screening Trial Cohort. BMC Cancer 9:84

105. Lahmann PH, Lissner L, Gullberg B, Olsson H, Berglund G (2003) A prospective study of adiposity and postmenopausal breast cancer risk: the Malmo Diet and Cancer Study. Int J Cancer 103(2):246-252

106. Lahmann PH, Hoffmann K, Allen N, van Gils CH, Khaw KT, Tehard B et al (2004) Body size and breast cancer risk: findings from the European Prospective Investigation into Cancer And Nutrition (EPIC). Int J Cancer 111(5):762-771

107. Lahmann PH, Schulz M, Hoffmann K, Boeing H, Tjonneland A, Olsen A et al (2005) Long-term weight change and breast cancer risk: the European prospective investigation into cancer and nutrition (EPIC). Br J Cancer 93(5):582-589

108. Lee IM, Rexrode KM, Cook NR, Hennekens CH, Burin JE (2001) Physical activity and breast cancer risk: the Women's Health Study (United States). Cancer Causes Control 12(2):137-145

109. Lee SY, Kim MT, Kim SW, Song MS, Yoon SJ (2003) Effect of lifetime lactation on breast cancer risk: a Korean women's cohort study. Int J Cancer 105(3):390-393

110. Leitzmann MF, Moore SC, Peters TM, Lacey JV Jr, Schatzkin A, Schairer C et al (2008) Prospective study of physical activity and risk of postmenopausal breast cancer. Breast Cancer Res 10(5):R92

111. Li HL, Gao YT, Li Q, Liu DK (2006) Anthropometry and female breast cancer: a prospective cohort study in urban Shanghai. Zhonghua Liu Xing Bing Xue Za Zhi 27(6):488-493

112. Liu Y, Warren AS, Wen W, Gao YT, Lan Q, Rothman N et al (2016) Prospective cohort study of general and central obesity, weight change trajectory and risk of major cancers among Chinese women. Int J Cancer 139(7):1461-1470

113. London SJ, Colditz GA, Stampfer MJ, Willett WC, Rosner B, Speizer FE (1989) Prospective study of relative weight, height, and risk of breast cancer. JAMA 262(20):2853-2858

114. Lukanova A, Bjor O, Kaaks R, Lenner P, Lindahl B, Hallmans $\mathrm{G}$ et al (2006) Body mass index and cancer: results from the Northern Sweden Health and Disease Cohort. Int J Cancer 118(2):458-466

115. Lundqvist E, Kaprio J, Verkasalo PK, Pukkala E, Koskenvuo M, Soderberg KC et al (2007) Co-twin control and cohort analyses of body mass index and height in relation to breast, prostate, ovarian, corpus uteri, colon and rectal cancer among Swedish and Finnish twins. Int J Cancer 121(4):810-818

116. Luoto R, Latikka P, Pukkala E, Hakulinen T, Vihko V (2000) The effect of physical activity on breast cancer risk: a cohort study of 30,548 women. Eur J Epidemiol 16(10):973-980

117. Ma H, Xu X, Clague J, Lu Y, Togawa K, Wang SS et al (2016) Recreational physical activity and risk of triple negative breast cancer in the California Teachers Study. Breast Cancer Res 18(1):62

118. Macinnis RJ, English DR, Gertig DM, Hopper JL, Giles GG (2004) Body size and composition and risk of postmenopausal breast cancer. Cancer Epidemiol Biomark Prev 13(12):2117-2125

119. Manders P, Pijpe A, Hooning MJ, Kluijt I, Vasen HF, Hoogerbrugge $\mathrm{N}$ et al (2011) Body weight and risk of breast cancer in BRCA1/2 mutation carriers. Breast Cancer Res Treat 126(1):193-202

120. Manjer J, Kaaks R, Riboli E, Berglund G (2001) Risk of breast cancer in relation to anthropometry, blood pressure, blood lipids and glucose metabolism: a prospective study within the Malmo Preventive Project. Eur J Cancer Prev 10(1):33-42

121. Maruti SS, Willett WC, Feskanich D, Rosner B, Colditz GA (2008) A prospective study of age-specific physical activity and premenopausal breast cancer. J Natl Cancer Inst 100(10):728-737

122. McTiernan A, Kooperberg C, White E, Wilcox S, Coates R, Adams-Campbell LL et al (2003) Recreational physical activity and the risk of breast cancer in postmenopausal women: the Women's Health Initiative Cohort Study. JAMA 290(10):1331-1336

123. Mellemkjaer L, Bigaard J, Tjonneland A, Christensen J, Thomsen B, Johansen C et al (2006) Body composition and breast cancer in postmenopausal women: a Danish prospective cohort study. Obesity (Silver Spring) 14(10):1854-1862

124. Mertens AJ, Sweeney C, Shahar E, Rosamond WD, Folsom AR (2006) Physical activity and breast cancer incidence in middleaged women: a prospective cohort study. Breast Cancer Res Treat 97(2):209-214

125. Miao JJ, Cederholm J, Gudbjornsdottir S (2014) Excess body weight and cancer risk in patients with type 2 diabetes who were registered in Swedish National Diabetes Register-register-based cohort study in Sweden. PLoS ONE 9(9):e105868

126. Michels KB, Terry KL, Eliassen AH, Hankinson SE, Willett WC (2012) Adult weight change and incidence of premenopausal breast cancer. Int J Cancer 130(4):902-909

127. Michels KB, Terry KL, Willett WC (2006) Longitudinal study on the role of body size in premenopausal breast cancer. Arch Intern Med 166(21):2395-2402

128. Moore DB, Folsom AR, Mink PJ, Hong CP, Anderson KE, Kushi LH (2000) Physical activity and incidence of postmenopausal breast cancer. Epidemiology 11(3):292-296

129. Moradi T, Adami HO, Bergstrom R, Gridley G, Wolk A, Gerhardsson $\mathrm{M}$ et al (1999) Occupational physical activity and risk for breast cancer in a nationwide cohort study in Sweden. Cancer Causes Control 10(5):423-430

130. Morimoto LM, White E, Chen Z, Chlebowski RT, Hays J, Kuller L et al (2002) Obesity, body size, and risk of postmenopausal breast cancer: the Women's Health Initiative (United States). Cancer Causes Control 13(8):741-751

131. Muti P, Stanulla M, Micheli A, Krogh V, Freudenheim JL, Yang $\mathrm{J}$ et al (2000) Markers of insulin resistance and sex steroid hormone activity in relation to breast cancer risk: a prospective analysis of abdominal adiposity, sebum production, and hirsutism (Italy). Cancer Causes Control 11(8):721-730

132. Neuhouser ML, Aragaki AK, Prentice RL, Manson JE, Chlebowski R, Carty CL et al (2015) Overweight, obesity, and 
postmenopausal invasive breast cancer risk: a secondary analysis of the Women's Health Initiative Randomized Clinical Trials. JAMA Oncol 1(5):611-621

133. Nitta J, Nojima M, Ohnishi H, Mori M, Wakai K, Suzuki S et al (2016) Weight gain and alcohol drinking associations with breast cancer risk in Japanese postmenopausal women-results from the Japan Collaborative Cohort (JACC) study. Asian Pac J Cancer Prev 17(3):1437-1443

134. Nomura SJ, Dash C, Rosenberg L, Palmer J, Adams-Campbell LL (2016) Sedentary time and breast cancer incidence in African American women. Cancer Causes Control 27(10):1239-1252

135. Harding JL, Shaw JE, Anstey KJ, Adams R, Balkau B, BrennanOlsen SL et al (2015) Comparison of anthropometric measures as predictors of cancer incidence: a pooled collaborative analysis of 11 Australian cohorts. Int J Cancer 137(7):1699-1708

136. Palmer JR, Adams-Campbell LL, Boggs DA, Wise LA, Rosenberg L (2007) A prospective study of body size and breast cancer in black women. Cancer Epidemiol Biomark Prev 16(9):1795-1802

137. Parker ED, Folsom AR (2003) Intentional weight loss and incidence of obesity-related cancers: the Iowa Women's Health Study. Int J Obes Relat Metab Disord 27(12):1447-1452

138. Patel AV, Callel EE, Bernstein L, Wu AH, Thun MJ (2003) Recreational physical activity and risk of postmenopausal breast cancer in a large cohort of US women. Cancer Causes Control 14(6):519-529

139. Peters TM, Schatzkin A, Gierach GL, Moore SC, Lacey JV Jr, Wareham NJ et al (2009) Physical activity and postmenopausal breast cancer risk in the NIH-AARP diet and health study. Cancer Epidemiol Biomark Prev 18(1):289-296

140. Petrelli JM, Calle EE, Rodriguez C, Thun MJ (2002) Body mass index, height, and postmenopausal breast cancer mortality in a prospective cohort of US women. Cancer Causes Control 13(4):325-332

141. Phipps AI, Chlebowski RT, Prentice R, McTiernan A, Stefanick ML, Wactawski-Wende J et al (2011) Body size, physical activity, and risk of triple-negative and estrogen receptor-positive breast cancer. Cancer Epidemiol Biomark Prev 20(3):454-463

142. Radimer KL, Ballard-Barbash R, Miller JS, Fay MP, Schatzkin A, Troiano R et al (2004) Weight change and the risk of lateonset breast cancer in the original Framingham cohort. Nutr Cancer 49(1):7-13

143. Reeves GK, Pirie K, Beral V, Green J, Spencer E, Bull D (2007) Cancer incidence and mortality in relation to body mass index in the Million Women Study: cohort study. BMJ 335(7630):1134

144. Reinier KS, Vacek PM, Geller BM (2007) Risk factors for breast carcinoma in situ versus invasive breast cancer in a prospective study of pre- and post-menopausal women. Breast Cancer Res Treat 103(3):343-348

145. Rinaldi S, Key TJ, Peeters PH, Lahmann PH, Lukanova A, Dossus L et al (2006) Anthropometric measures, endogenous sex steroids and breast cancer risk in postmenopausal women: a study within the EPIC cohort. Int J Cancer 118(11):2832-2839

146. Rintala B, Pukkala E, Paakkulainen HT, Vihko VJ (2002) Selfexperienced physical workload and risk of breast cancer. Scand J Work Environ Health 28(3):158-162

147. Rintala P, Pukkala E, Laara E, Vihko V (2003) Physical activity and breast cancer risk among female physical education and language teachers: a 34-year follow-up. Int J Cancer 107(2):268-270

148. Ritte R, Lukanova A, Berrino F, Dossus L, Tjonneland A, Olsen A et al (2012) Adiposity, hormone replacement therapy use and breast cancer risk by age and hormone receptor status: a large prospective cohort study. Breast Cancer Res 14(3):R76

149. Rosenberg L, Palmer JR, Bethea TN, Ban Y, Kipping-Ruane K, Adams-Campbell LL (2014) A prospective study of physical activity and breast cancer incidence in African-American women. Cancer Epidemiol Biomark Prev 23(11):2522-2531

150. Rosner B, Eliassen AH, Toriola AT, Chen WY, Hankinson SE, Willett WC et al (2017) Weight and weight changes in early adulthood and later breast cancer risk. Int J Cancer 140(9):2003-2014

151. Schnohr P, Gronbaek M, Petersen L, Hein HO, Sorensen TI (2005) Physical activity in leisure-time and risk of cancer: 14-year follow-up of 28,000 Danish men and women. Scand J Public Health 33(4):244-249

152. Schonfeld SJ, Pfeiffer RM, Lacey JV Jr, de Berrington GA, Doody MM, Greenlee RT et al (2011) Hormone-related risk factors and postmenopausal breast cancer among nulliparous versus parous women: an aggregated study. Am J Epidemiol 173(5):509-517

153. Sebastiani F, Cortesi L, Sant M, Lucarini V, Cirilli C, De ME et al (2016) Increased incidence of breast cancer in postmenopausal women with high body mass index at the Modena Screening Program. J Breast Cancer 19(3):283-291

154. Sellers TA, Davis J, Cerhan JR, Vierkant RA, Olson JE, Pankratz VS et al (2002) Interaction of waist/hip ratio and family history on the risk of hormone receptor-defined breast cancer in a prospective study of postmenopausal women. Am J Epidemiol 155(3):225-233

155. Sesso HD, Paffenbarger RS Jr, Lee IM (1998) Physical activity and breast cancer risk in the College Alumni Health Study (United States). Cancer Causes Control 9(4):433-439

156. Setiawan VW, Monroe KR, Wilkens LR, Kolonel LN, Pike MC, Henderson BE (2009) Breast cancer risk factors defined by estrogen and progesterone receptor status: the multiethnic cohort study. Am J Epidemiol 169(10):1251-1259

157. Silvera SA, Jain M, Howe GR, Miller AB, Rohan TE (2006) Energy balance and breast cancer risk: a prospective cohort study. Breast Cancer Res Treat 97(1):97-106

158. Song YM, Sung J, Ha M (2008) Obesity and risk of cancer in postmenopausal Korean women. J Clin Oncol 26(20):3395-3402

159. Sonnenschein E, Toniolo P, Terry MB, Bruning PF, Kato I, Koenig KL et al (1999) Body fat distribution and obesity in pre- and postmenopausal breast cancer. Int $\mathrm{J}$ Epidemiol 28(6):1026-1031

160. Steindorf K, Ritte R, Eomois PP, Lukanova A, Tjonneland A, Johnsen NF et al (2013) Physical activity and risk of breast cancer overall and by hormone receptor status: the European prospective investigation into cancer and nutrition. Int J Cancer 132(7):1667-1678

161. Suzuki R, Rylander-Rudqvist T, Ye W, Saji S, Wolk A (2006) Body weight and postmenopausal breast cancer risk defined by estrogen and progesterone receptor status among Swedish women: a prospective cohort study. Int J Cancer 119(7):1683-1689

162. Suzuki R, Iwasaki M, Inoue M, Sasazuki S, Sawada N, Yamaji $\mathrm{T}$ et al (2011) Body weight at age 20 years, subsequent weight change and breast cancer risk defined by estrogen and progesterone receptor status-the Japan public health center-based prospective study. Int J Cancer 129(5):1214-1224

163. Suzuki R, Iwasaki M, Yamamoto S, Inoue M, Sasazuki S, Sawada $\mathrm{N}$ et al (2011) Leisure-time physical activity and breast cancer risk defined by estrogen and progesterone receptor status-the Japan Public Health Center-based Prospective Study. Prev Med 52(3-4):227-233

164. Tehard B, Friedenreich CM, Oppert JM, Clavel-Chapelon F (2006) Effect of physical activity on women at increased risk of breast cancer: results from the E3N cohort study. Cancer Epidemiol Biomarkers Prev 15(1):57-64 
165. Tehard B, Clavel-Chapelon F (2006) Several anthropometric measurements and breast cancer risk: results of the $\mathrm{E} 3 \mathrm{~N}$ cohort study. Int J Obes (Lond) 30(1):156-163

166. Thune I, Brenn T, Lund E, Gaard M (1997) Physical activity and the risk of breast cancer. N Engl J Med 336(18):1269-1275

167. Torio CM, Klassen AC, Curriero FC, Caballero B, Helzlsouer K (2010) The modifying effect of social class on the relationship between body mass index and breast cancer incidence. Am J Public Health 100(1):146-151

168. Tornberg SA, Carstensen JM (1994) Relationship between Quetelet's index and cancer of breast and female genital tract in 47,000 women followed for 25 years. Br J Cancer 69(2):358-361

169. Tulinius H, Sigfusson N, Sigvaldason H, Bjarnadottir K, Tryggvadottir L (1997) Risk factors for malignant diseases: a cohort study on a population of 22,946 Icelanders. Cancer Epidemiol Biomark Prev 6(11):863-873

170. van den Brandt PA, Dirx MJ, Ronckers CM, van den Hoogen P, Goldbohm RA (1997) Height, weight weight change, and postmenopausal breast cancer risk: The Netherlands Cohort Study. Cancer Causes Control 8(1):39-47

171. van den Brandt PA, Spiegelman D, Yaun SS, Adami HO, Beeson L, Folsom AR et al (2000) Pooled analysis of prospective cohort studies on height, weight, and breast cancer risk. Am J Epidemiol 152(6):514-527

172. Vatten LJ, Kvinnsland S (1990) Body mass index and risk of breast cancer. A prospective study of 23,826 Norwegian women. Int J Cancer 45(3):440-444

173. Vatten LJ, Kvinnsland S (1992) Prospective study of height, body mass index and risk of breast cancer. Acta Oncol 31(2):195-200

174. Wada K, Nagata C, Tamakoshi A, Matsuo K, Oze I, Wakai K et al (2014) Body mass index and breast cancer risk in Japan: a pooled analysis of eight population-based cohort studies. Ann Oncol 25(2):519-524

175. Weiderpass E, Braaten T, Magnusson C, Kumle M, Vainio H, Lund E et al (2004) A prospective study of body size in different periods of life and risk of premenopausal breast cancer. Cancer Epidemiol Biomark Prev 13(7):1121-1127

176. Welti LM, Beavers DP, Caan BJ, Sangi-Haghpeykar H, Vitolins MZ, Beavers KM (2017) Weight fluctuation and cancer risk in postmenopausal women: the women's health initiative. Cancer Epidemiol Biomark Prev 26(5):779-786

177. White AJ, Nichols HB, Bradshaw PT, Sandler DP (2015) Overall and central adiposity and breast cancer risk in the Sister Study. Cancer 121(20):3700-3708

178. White KK, Park SY, Kolonel LN, Henderson BE, Wilkens LR (2012) Body size and breast cancer risk: the Multiethnic Cohort. Int J Cancer 131(5):E705-E716

179. Whitlock G, Lewington S, Sherliker P, Clarke R, Emberson J, Halsey J et al (2009) Body-mass index and cause-specific mortality in 900000 adults: collaborative analyses of 57 prospective studies. Lancet 373(9669):1083-1096

180. Xue F, Rosner B, Eliassen H, Michels KB (2016) Body fatness throughout the life course and the incidence of premenopausal breast cancer. Int J Epidemiol 45(4):1103-1112

181. Zhang X, Eliassen AH, Tamimi RM, Hazra A, Beck AH, Brown $M$ et al (2015) Adult body size and physical activity in relation to risk of breast cancer according to tumor androgen receptor status. Cancer Epidemiol Biomark Prev 24(6):962-968

182. Suzuki S, Kojima M, Tokudome S, Mori M, Sakauchi F, Fujino $Y$ et al (2008) Effect of physical activity on breast cancer risk: findings of the Japan collaborative cohort study. Cancer Epidemiol Biomark Prev 17(12):3396-3401

183. Liu Y, Tobias DK, Sturgeon KM, Rosner B, Malik V, Cespedes E et al (2016) Physical activity from menarche to first pregnancy and risk of breast cancer. Int J Cancer 139(6):1223-1230
184. Saris WH, Blair SN, van Baak MA, Eaton SB, Davies PS, Di PL et al (2003) How much physical activity is enough to prevent unhealthy weight gain? Outcome of the IASO 1st Stock Conference and consensus statement. Obes Rev 4(2):101-114

185. Gleeson M (1985) (2007) Immune function in sport and exercise. J Appl Physiol 103(2):693-699

186. Bernstein L, Ross RK, Lobo RA, Hanisch R, Krailo MD, Henderson BE (1987) The effects of moderate physical activity on menstrual cycle patterns in adolescence: implications for breast cancer prevention. Br J Cancer 55(6):681-685

187. Moore SC, Lee IM, Weiderpass E, Campbell PT, Sampson JN, Kitahara CM et al (2016) Association of leisure-time physical activity with risk of 26 types of cancer in 1.44 million adults. JAMA Intern Med 176(6):816-825

188. Brown WJ, Bauman AE, Owen N (2009) Stand up, sit down, keep moving: turning circles in physical activity research? Br J Sports Med 43(2):86-88

189. Owen N, Healy GN, Matthews CE, Dunstan DW (2010) Too much sitting: the population health science of sedentary behavior. Exerc Sport Sci Rev 38(3):105-113

190. Kerr J, Anderson C, Lippman SM (2017) Physical activity, sedentary behaviour, diet, and cancer: an update and emerging new evidence. Lancet Oncol 18(8):e457-e471

191. Schoemaker MJ, Nichols HB, Wright LB, Brook MN, Jones ME, O'Brien KM et al (2018) Association of body mass index and age with subsequent breast cancer risk in premenopausal women. JAMA Oncol 4:e181771

192. Russo J, Russo IH (1993) Development pattern of human breast and susceptibility to carcinogenesis. Eur J Cancer Prev 2(Suppl 3):85-100

193. Berkey CS, Frazier AL, Gardner JD, Colditz GA (1999) Adolescence and breast carcinoma risk. Cancer 85(11):2400-2409

194. Schauer DP, Feigelson HS, Koebnick C, Caan B, Weinmann S, Leonard AC et al (2017) Bariatric surgery and the risk of cancer in a large multisite cohort. Ann Surg 269:95-101

195. Harvie M, Howell A, Vierkant RA, Kumar N, Cerhan JR, Kelemen LE et al (2005) Association of gain and loss of weight before and after menopause with risk of postmenopausal breast cancer in the Iowa women's health study. Cancer Epidemiol Biomark Prev 14(3):656-661

196. Byers T, Sedjo RL (2011) Does intentional weight loss reduce cancer risk? Diabetes Obes Metab 13(12):1063-1072

197. McTiernan A, Tworoger SS, Ulrich CM, Yasui Y, Irwin ML, Rajan KB et al (2004) Effect of exercise on serum estrogens in postmenopausal women: a 12-month randomized clinical trial. Cancer Res 64(8):2923-2928

198. Campbell KL, Foster-Schubert KE, Alfano CM, Wang CC, Wang CY, Duggan CR et al (2012) Reduced-calorie dietary weight loss, exercise, and sex hormones in postmenopausal women: randomized controlled trial. J Clin Oncol 30(19):2314-2326

199. Collaborative Group on Hormonal Factors in Breast Cancer (1997) Breast cancer and hormone replacement therapy: collaborative reanalysis of data from 51 epidemiological studies of 52,705 women with breast cancer and 108,411 women without breast cancer. Lancet 350(9084):1047-1059

200. Gaudet MM, Gierach GL, Carter BD, Luo J, Milne RL, Weiderpass E et al (2018) Pooled analysis of nine cohorts reveals breast cancer risk factors by tumor molecular subtype. Cancer Res 78(20):6011-6021

201. Guo W, Key TJ, Reeves GK (2018) Adiposity and breast cancer risk in postmenopausal women: Results from the UK Biobank prospective cohort. Int J Cancer 143(5):1037-1046

202. Tchernof A, Despres JP (2013) Pathophysiology of human visceral obesity: an update. Physiol Rev 93(1):359-404 
203. Deurenberg P, Deurenberg-Yap M, Guricci S (2002) Asians are different from Caucasians and from each other in their body mass index/body fat per cent relationship. Obes Rev 3(3):141-146

204. Siiteri PK (1987) Adipose tissue as a source of hormones. Am J Clin Nutr 45(1 Suppl):277-282

205. Iyengar NM, Gucalp A, Dannenberg AJ, Hudis CA (2016) Obesity and cancer mechanisms: tumor microenvironment and inflammation. J Clin Oncol 34(35):4270-4276

206. Stoll BA (1997) Impaired ovulation and breast cancer risk. Eur J Cancer 33(10):1532-1535

207. Kaaks R, Tikk K, Sookthai D, Schock H, Johnson T, Tjonneland A et al (2014) Premenopausal serum sex hormone levels in relation to breast cancer risk, overall and by hormone receptor status-results from the EPIC cohort. Int J Cancer 134(8): 1947-1957

208. Eliassen AH, Missmer SA, Tworoger SS, Spiegelman D, Barbieri RL, Dowsett M et al (2006) Endogenous steroid hormone concentrations and risk of breast cancer among premenopausal women. J Natl Cancer Inst 98(19):1406-1415

209. Key TJ, Appleby PN, Reeves GK, Travis RC, Alberg AJ, Barricarte A et al (2013) Sex hormones and risk of breast cancer in premenopausal women: a collaborative reanalysis of individual participant data from seven prospective studies. Lancet Oncol 14(10):1009-1019

210. Zhao H, Wang J, Fang D, Lee O, Chatterton RT, Stearns V et al (2018) Adiposity results in metabolic and inflammation differences in premenopausal and postmenopausal women consistent with the difference in breast cancer risk. Horm Cancer 9:229-239

211. Stoll BA (2002) Upper abdominal obesity, insulin resistance and breast cancer risk. Int J Obes Relat Metab Disord 26(6):747-753

212. Vona-Davis L, Rose DP (2012) Type 2 diabetes and obesity metabolic interactions: common factors for breast cancer risk and novel approaches to prevention and therapy. Curr Diabetes Rev 8(2):116-130

213. Iyengar NM, Hudis CA, Dannenberg AJ (2015) Obesity and cancer: local and systemic mechanisms. Annu Rev Med 66:297-309

214. Chan DS, Bandera EV, Greenwood DC, Norat T (2015) Circulating $\mathrm{C}$-reactive protein and breast cancer risk-systematic literature review and meta-analysis of prospective cohort studies. Cancer Epidemiol Biomarkers Prev 24(10):1439-1449

215. Hursting SD, Digiovanni J, Dannenberg AJ, Azrad M, Leroith D, Demark-Wahnefried W et al (2012) Obesity, energy balance, and cancer: new opportunities for prevention. Cancer Prev Res (Phila) 5(11):1260-1272

216. Kyrgiou M, Kalliala I, Markozannes G, Gunter MJ, Paraskevaidis E, Gabra H et al (2017) Adiposity and cancer at major anatomical sites: umbrella review of the literature. BMJ 356:j477

217. Rezende LFM, Sa TH, Markozannes G, Rey-Lopez JP, Lee IM, Tsilidis KK et al (2018) Physical activity and cancer: an umbrella review of the literature including 22 major anatomical sites and 770000 cancer cases. Br J Sports Med 52(13):826-833

218. McTiernan A, Friedenreich CM, Katzmarzyk PT, Powell KE, Macko R, Buchner D et al (2019) Physical activity in cancer prevention and survival: a systematic review. Med Sci Sports Exerc 51(6):1252-1261

219. Gao C, Patel CJ, Michailidou K, Peters U, Gong J, Schildkraut J et al (2016) Mendelian randomization study of adiposity-related traits and risk of breast, ovarian, prostate, lung and colorectal cancer. Int J Epidemiol 45(3):896-908

220. Guo Y, Warren AS, Shu XO, Michailidou K, Bolla MK, Wang Q et al (2016) Genetically predicted body mass index and breast cancer risk: mendelian randomization analyses of data from 145,000 women of european descent. PLoS Med 13(8):e1002105

221. Qian F, Wang S, Mitchell J, McGuffog L, Barrowdale D, Leslie $G$ et al (2018) Height and body mass index as modifiers of breast cancer risk in BRCA1/2 mutation carriers: a Mendelian randomization study. J Natl Cancer Inst 111:350-364

222. Shu X, Wu L, Khankari NK, Shu XO, Wang TJ, Michailidou $\mathrm{K}$ et al (2018) Associations of obesity and circulating insulin and glucose with breast cancer risk: a Mendelian randomization analysis. Int J Epidemiol. https://doi.org/10.1093/ije/dyy201

223. Bandera EV, Fay SH, Giovannucci E, Leitzmann MF, Marklew R, McTiernan A et al (2016) The use and interpretation of anthropometric measures in cancer epidemiology: a perspective from the world cancer research fund international continuous update project. Int J Cancer 139(11):2391-2397

224. Agnoli C, Berrino F, Abagnato CA, Muti P, Panico S, Crosignani $P$ et al (2010) Metabolic syndrome and postmenopausal breast cancer in the ORDET cohort: a nested case-control study. Nutr Metab Cardiovasc Dis 20(1):41-48

225. Bjorge T, Lukanova A, Jonsson H, Tretli S, Ulmer H, Manjer J et al (2010) Metabolic syndrome and breast cancer in the mecan (metabolic syndrome and cancer) project. Cancer Epidemiol Biomark Prev 19(7):1737-1745

226. Hartz AJ, He T (2013) Cohort study of risk factors for breast cancer in post menopausal women. Epidemiol Health 35:e2013003

227. Horn-Ross PL, Canchola AJ, Bernstein L, Neuhausen SL, Nelson DO, Reynolds P (2016) Lifetime body size and estrogen-receptor-positive breast cancer risk in the California Teachers Study cohort. Breast Cancer Res 18(1):132

228. Kerlikowske K, Gard CC, Tice JA, Ziv E, Cummings SR, Miglioretti DL (2017) Risk factors that increase risk of estrogen receptor-positive and -negative breast cancer. J Natl Cancer Inst 109:5

229. Le Marchand L, Kolonel LN, Earle ME, Mi MP (1988) Body size at different periods of life and breast cancer risk. Am J Epidemiol 128(1):137-152

230. Manjer J, Malina J, Berglund G, Bondeson L, Garne JP, Janzon L (2001) Breast cancer incidence in ex-smokers in relation to body mass index, weight gain and blood lipid levels. Eur J Cancer Prev 10(3):281-287

231. Hooper L, Anderson AS, Birch J, Forster AS, Rosenberg G, Bauld L et al (2017) Public awareness and healthcare professional advice for obesity as a risk factor for cancer in the UK: a cross-sectional survey. J Public Health (Oxf) 40:797-805

232. World Cancer Research Fund/American Institute for Cancer Research (2018) Continuous Update Project Expert Report 2018. Recommendations and public health and policy implications

Publisher's Note Springer Nature remains neutral with regard to jurisdictional claims in published maps and institutional affiliations. 